\title{
Insight into the mechanism of decarbonylation of methanol by ruthenium complexes; a deuterium labelling study
}

ESI

\section{Contents}

$1 \quad$ NMR spectra

2 Evidence for $\mathrm{o}-\mathrm{D}$ incorporation into coordinated $\mathrm{PPh}_{3}$

3 Hydride composition for the final product from reaction of $\left[\mathrm{RuHClP} \mathrm{P}_{3}\right]$ with $\mathrm{Na} / \mathrm{CD}_{3} \mathrm{OD}$.

$1 \quad$ NMR spectra

$\left[\mathrm{RuH}_{2}(\mathrm{CO})\left(\mathrm{PPh}_{3}\right)_{3}\right]$

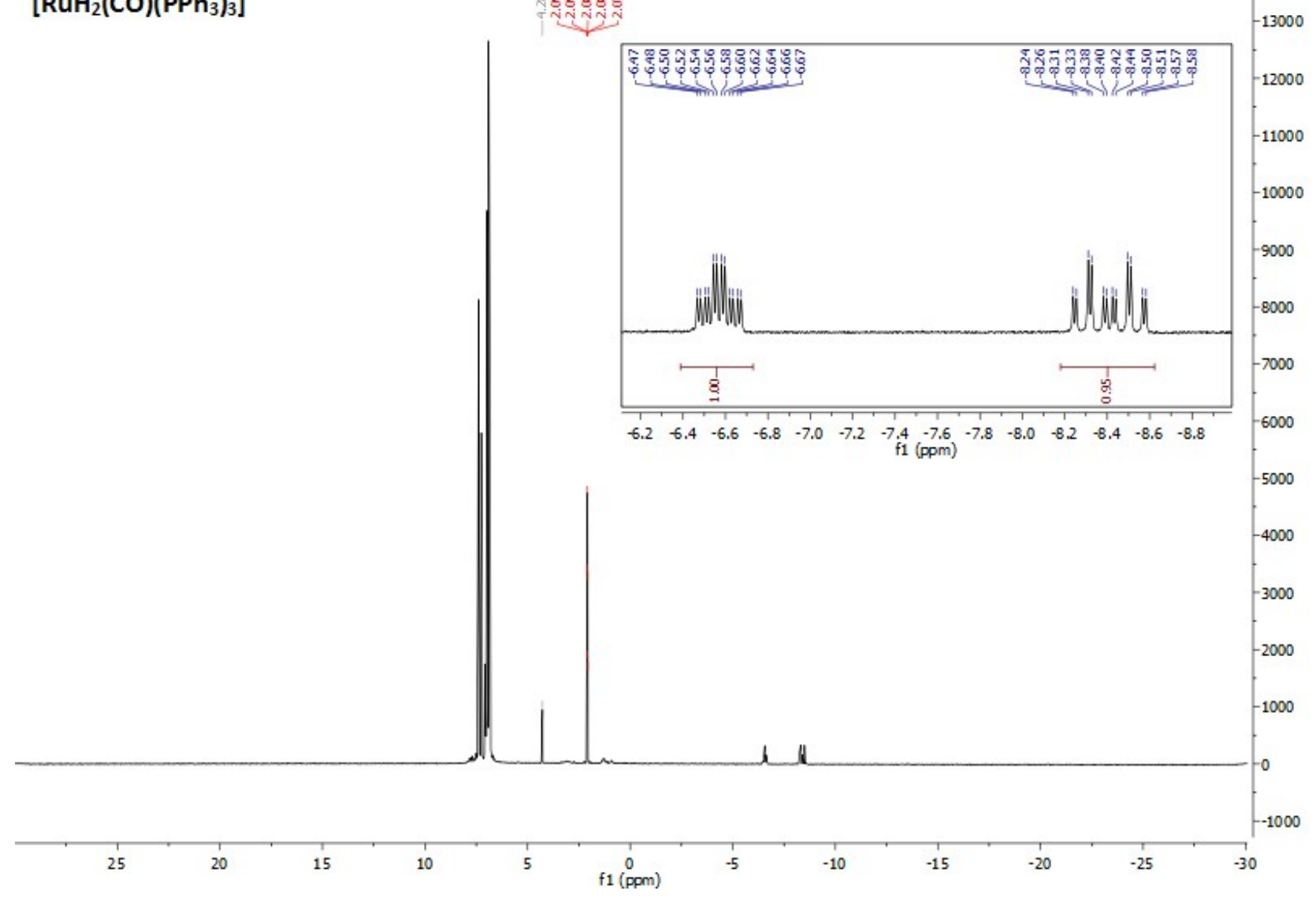

Figure $\mathrm{S} 1{ }^{1} \mathrm{H}$ NMR $\left(400 \mathrm{MHz}\right.$; toluene- $\left.d_{8}\right)$ of $\left[\mathrm{RuH}_{2}(\mathrm{CO})\left(\mathrm{PPh}_{3}\right)_{3}\right]$ 


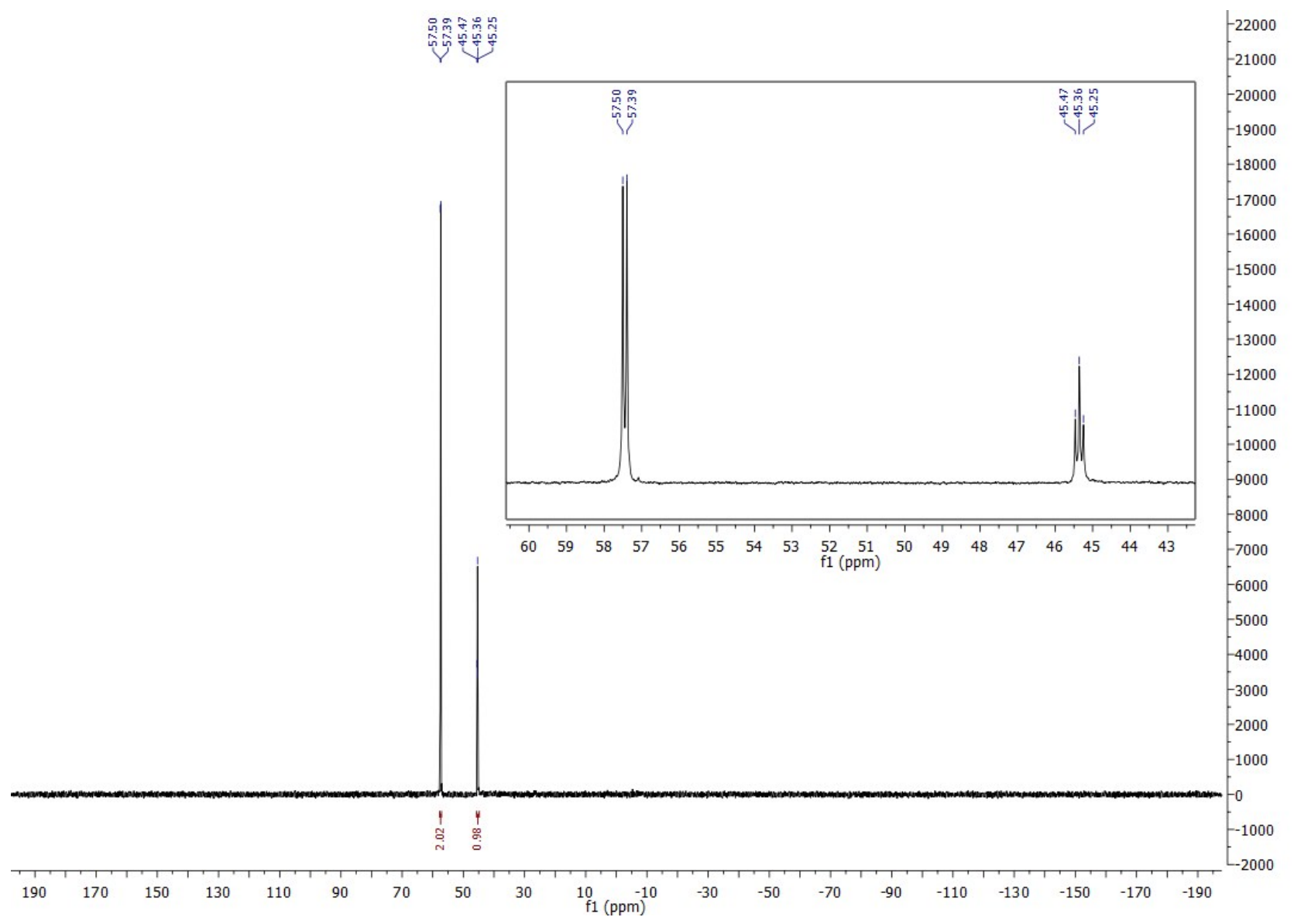

Figure S2 ${ }^{31} \mathrm{P}\left\{{ }^{1} \mathrm{H}\right\} \mathrm{NMR}\left(400 \mathrm{MHz}\right.$; toluene- $\left.d_{8}\right)$ of $\left[\mathrm{RuH}_{2}(\mathrm{CO})\left(\mathrm{PPh}_{3}\right)_{3}\right]$ 
1.2 Mixture $\left[\mathrm{RuHD}(\mathrm{CO})\left(\mathrm{PPh}_{3}\right)_{3}\right]$ (major species) and $\left[\mathrm{RuH}_{2}(\mathrm{CO})\left(\mathrm{PPh}_{3}\right)_{3}\right]($ minor species)

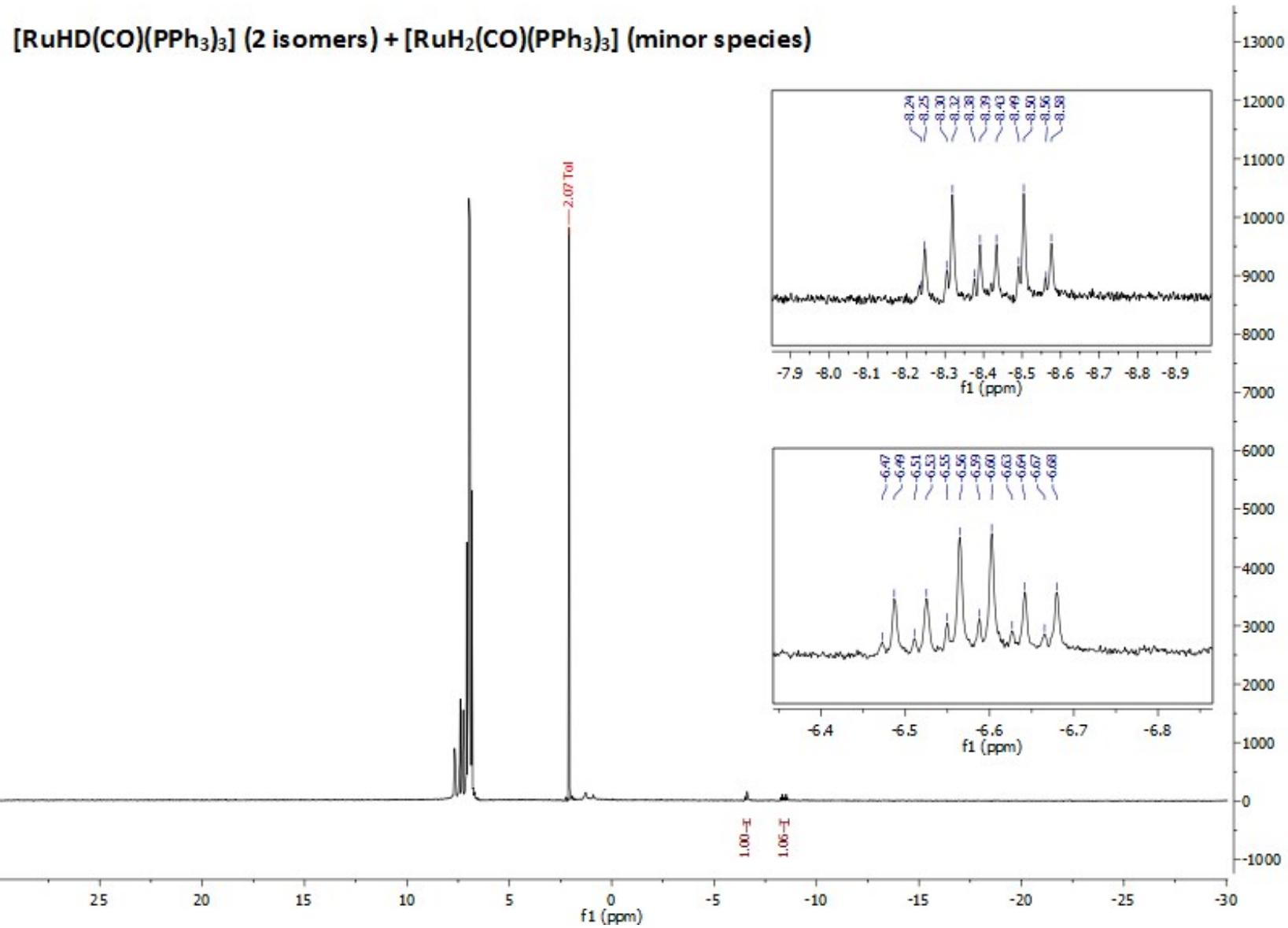

Figure S3 ${ }^{1} \mathrm{H}$ NMR $\left(400 \mathrm{MHz}\right.$; toluene- $\left.d_{8}\right)$ of $\left[\mathrm{RuHD}(\mathrm{CO})\left(\mathrm{PPh}_{3}\right)_{3}\right]\left(2\right.$ isomers) and $\left[\mathrm{RuH}_{2}(\mathrm{CO})\left(\mathrm{PPh}_{3}\right)_{3}\right]$ (minor species). 


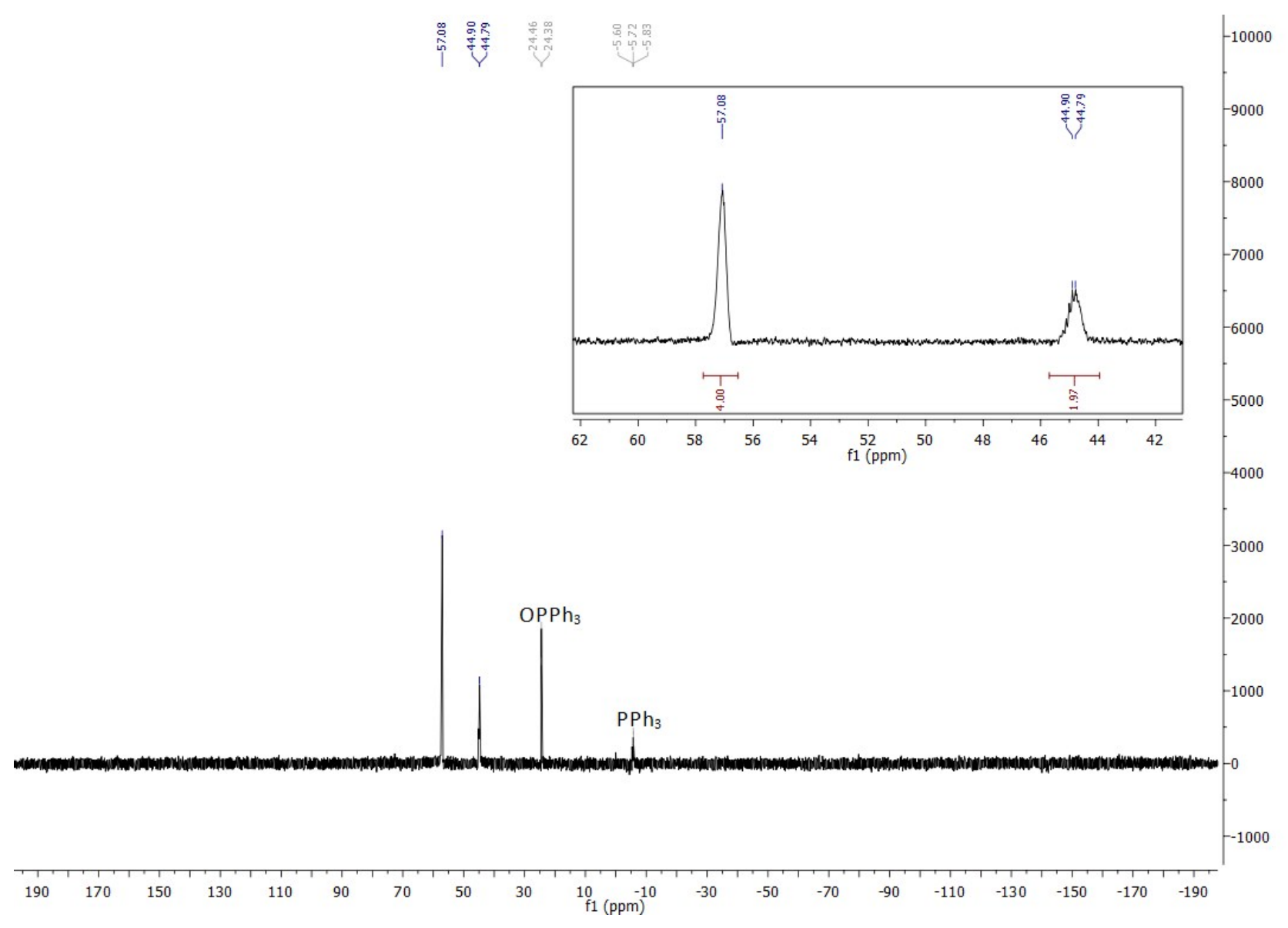

Figure S4 ${ }^{31} \mathrm{P}\left\{{ }^{1} \mathrm{H}\right\} \mathrm{NMR}\left(400 \mathrm{MHz}\right.$; toluene- $\left.d_{8}\right)$ of $\left[\mathrm{RuHD}(\mathrm{CO})\left(\mathrm{PPh}_{3}\right)_{3}\right]$ (2 isomers) and $\left[\mathrm{RuH}_{2}(\mathrm{CO})\left(\mathrm{PPh}_{3}\right)_{3}\right]\left(\mathrm{minor}^{2}\right.$ species). 


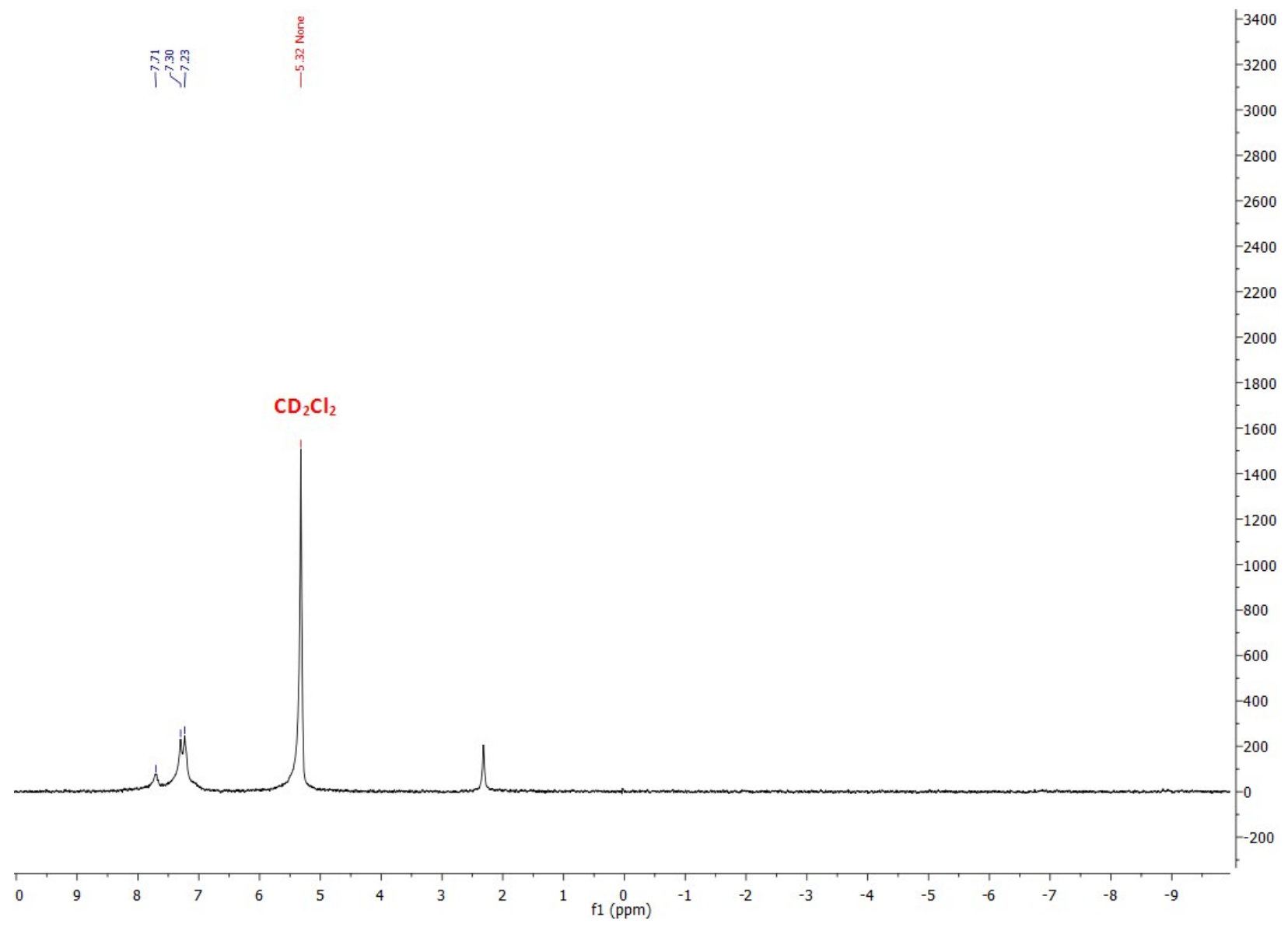

Figure S5 ${ }^{2} \mathrm{H}\left\{{ }^{1} \mathrm{H}\right\} \mathrm{NMR}\left(500 \mathrm{MHz} ; \mathrm{CH}_{2} \mathrm{Cl}_{2}\right)$ of $\left[\mathrm{RuHD}(\mathrm{CO})\left(\mathrm{PPh}_{3}\right)_{3}\right]$ (2 isomers) and $\left[\mathrm{RuH}_{2}(\mathrm{CO})\left(\mathrm{PPh}_{3}\right)_{3}\right]($ minor species). 


\subsection{Potential $\left[\mathrm{RuD}_{2}(\mathrm{CO})\left(\mathrm{PPh}_{3}\right)_{3}\right]$}

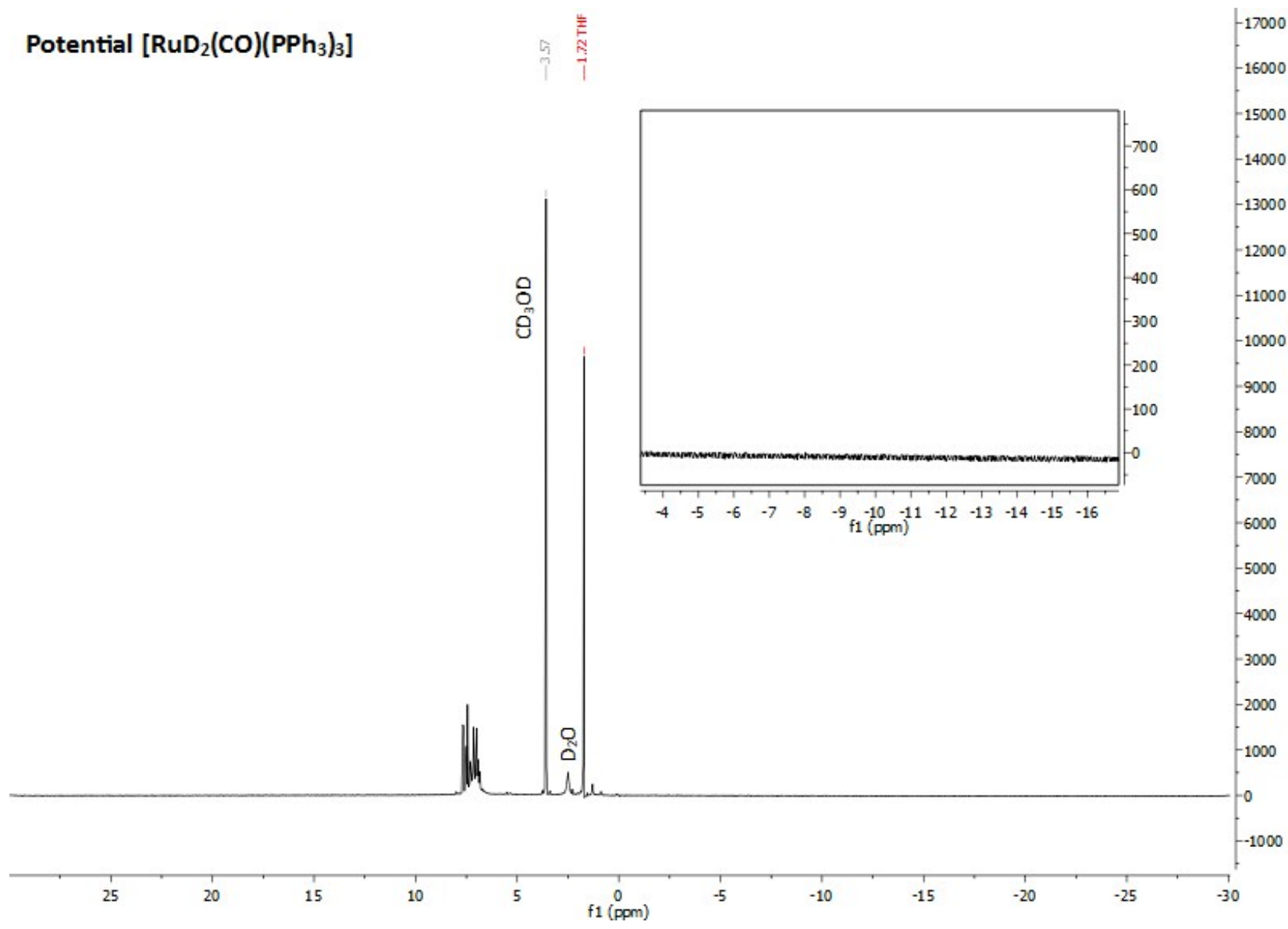

Figure $56{ }^{1} \mathrm{H}$ NMR $\left(400 \mathrm{MHz}\right.$; THF- $\left.d_{8}\right)$ of $\left[\mathrm{RuD}_{2}(\mathrm{CO})\left(\mathrm{PPh}_{3}\right)_{3}\right]$ 


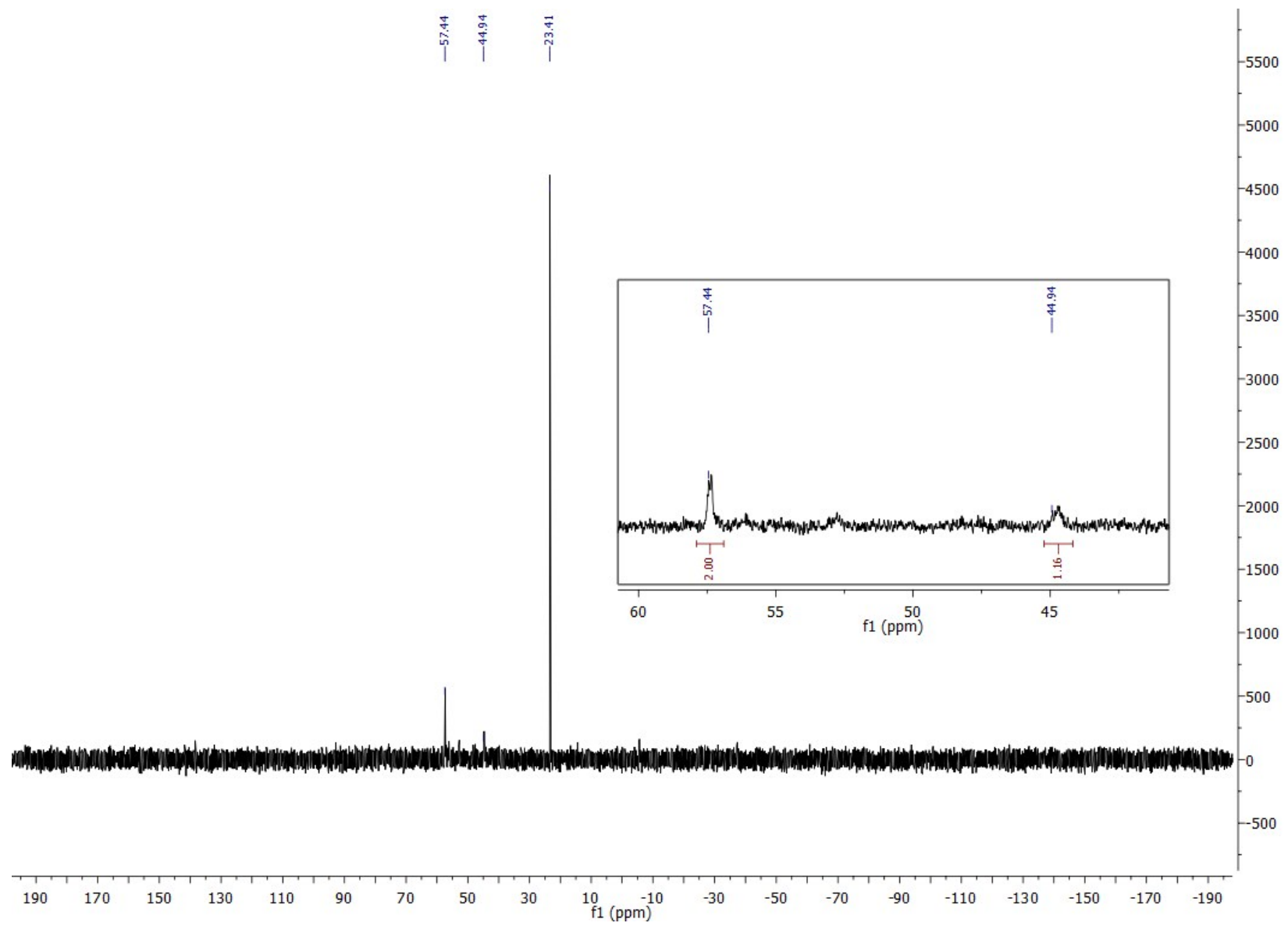

Figure S7 ${ }^{31} \mathrm{P}\left\{{ }^{1} \mathrm{H}\right\} \mathrm{NMR}\left(400 \mathrm{MHz}\right.$; THF- $\left.d_{8}\right)$ of $\left[\mathrm{RuD}_{2}(\mathrm{CO})\left(\mathrm{PPh}_{3}\right)_{3}\right]$ 
$1.4\left[\mathrm{RuH}_{2}\left({ }^{13} \mathrm{CO}\right)\left(\mathrm{PPh}_{3}\right)_{3}\right]$ (experiment used for determining the KIE)

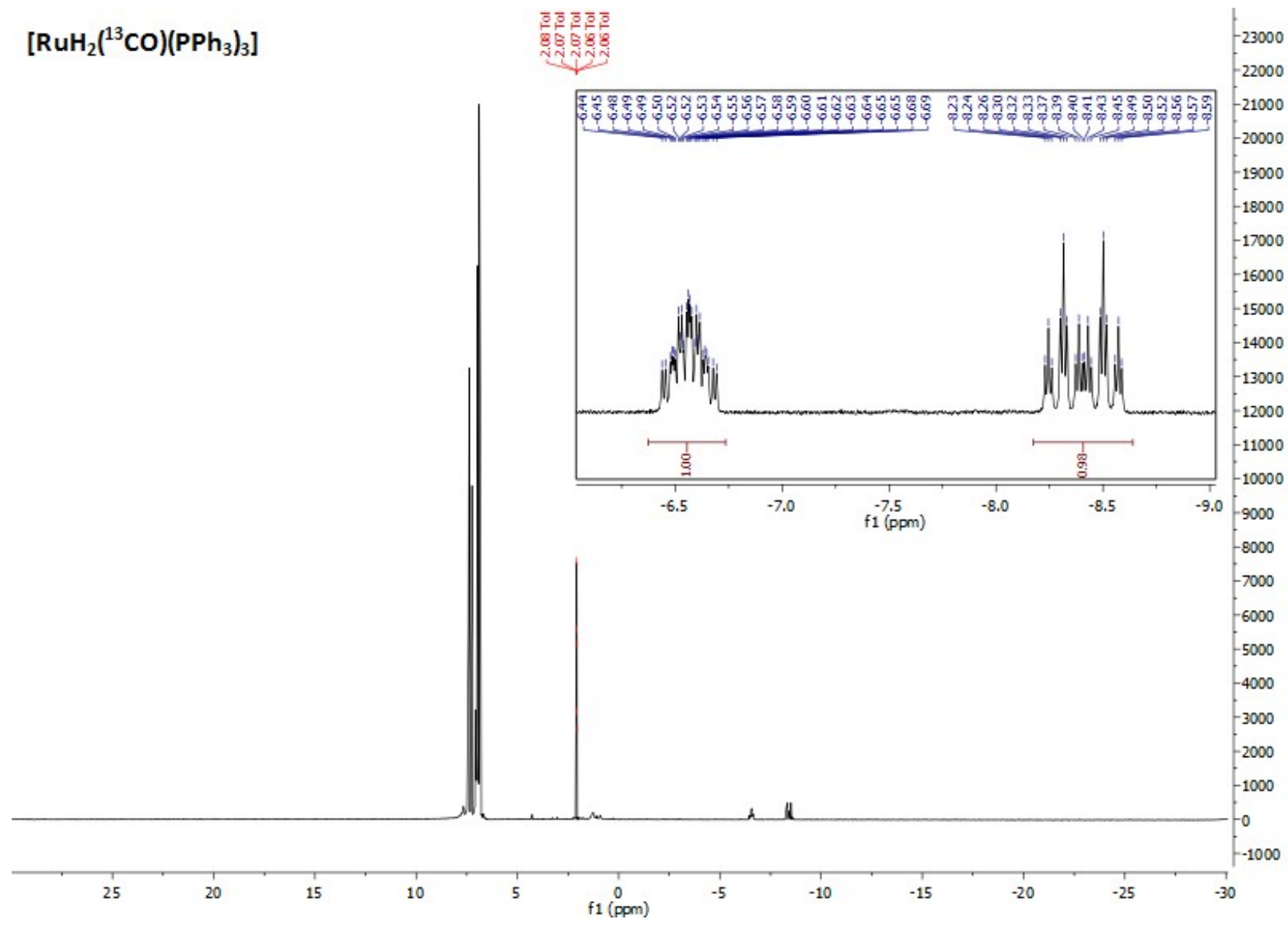

Figure $58{ }^{1} \mathrm{H}$ NMR $\left(400 \mathrm{MHz}\right.$; toluene- $\left.d_{8}\right)$ of $\left[\mathrm{RuH}_{2}\left({ }^{13} \mathrm{CO}\right)\left(\mathrm{PPh}_{3}\right)_{3}\right]$ 


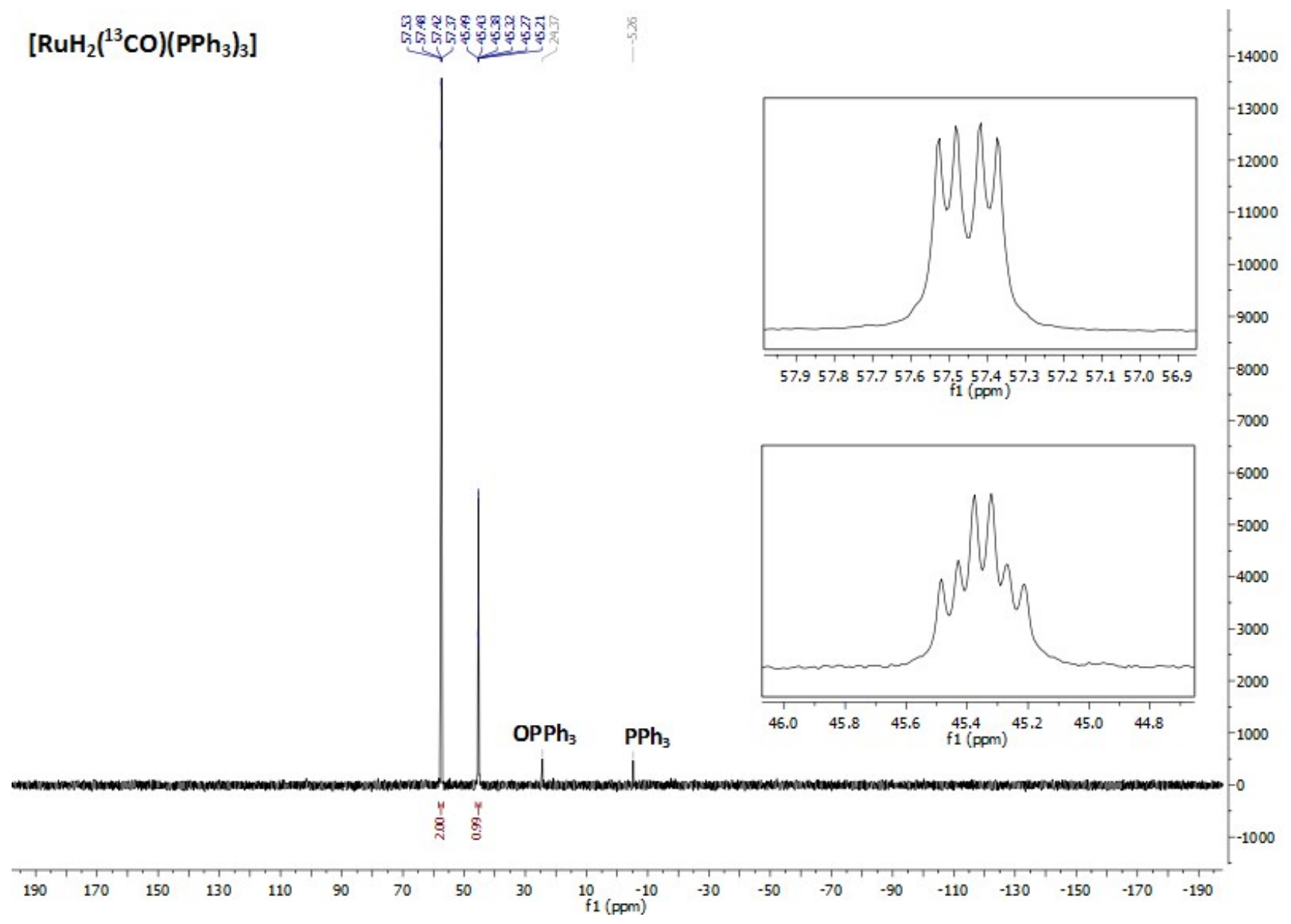

Figure S9 ${ }^{31} \mathrm{P}\left\{{ }^{1} \mathrm{H}\right\} \mathrm{NMR}\left(400 \mathrm{MHz}\right.$; toluene- $\left.d_{8}\right)$ of $\left[\mathrm{RuH}_{2}\left({ }^{13} \mathrm{CO}\right)\left(\mathrm{PPh}_{3}\right)_{3}\right]$ 


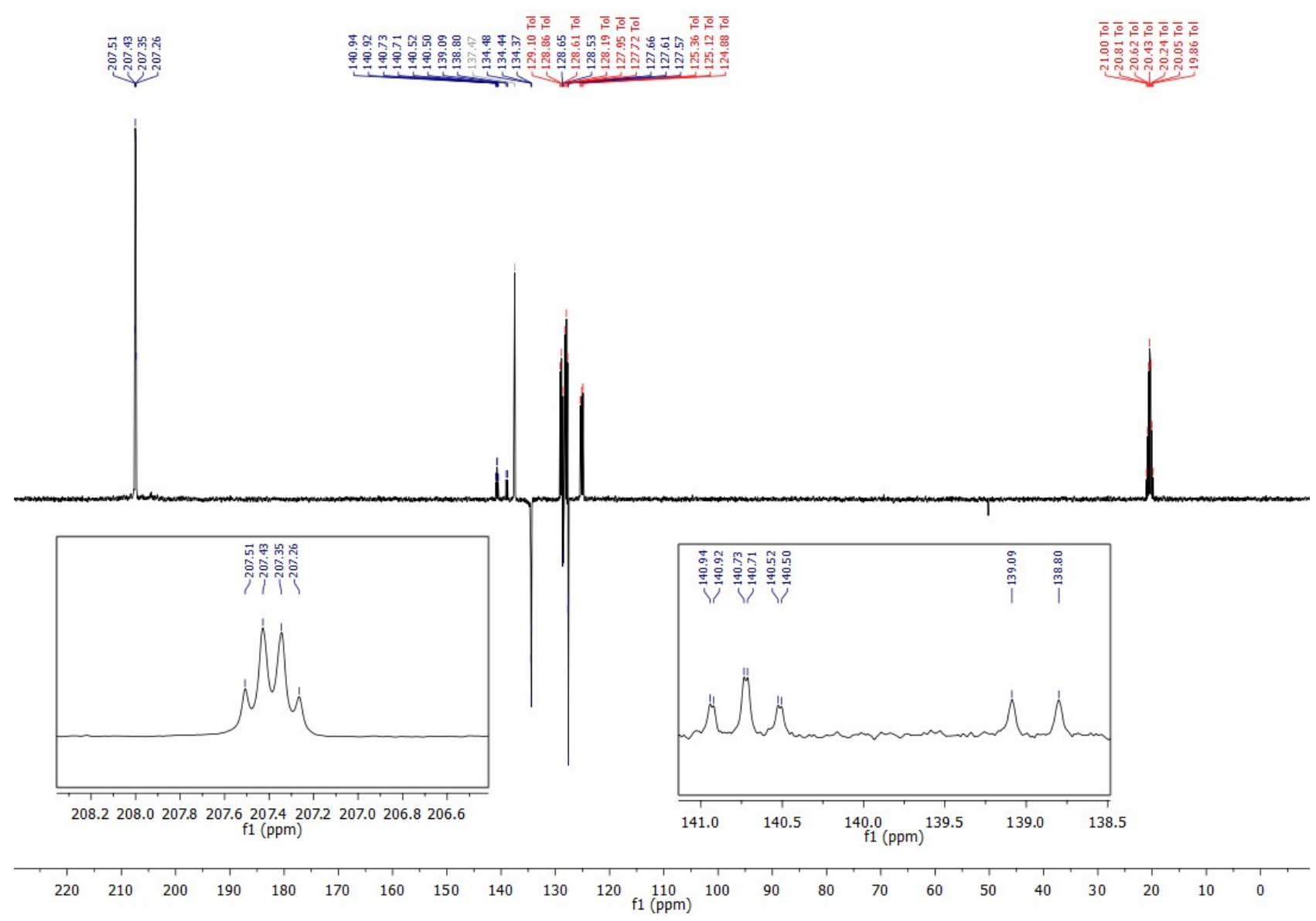

Figure $\mathrm{S10}{ }^{13} \mathrm{C}\left\{{ }^{1} \mathrm{H}\right\} \mathrm{NMR}\left(400 \mathrm{MHz}\right.$; toluene- $\left.d_{8}\right)$ of $\left[\mathrm{RuH}_{2}\left({ }^{13} \mathrm{CO}\right)\left(\mathrm{PPh}_{3}\right)_{3}\right]$ 
1.5 Mixture of $\left[\mathrm{RuH}_{2}\left({ }^{13} \mathrm{CO}\right)\left(\mathrm{PPh}_{3}\right)_{3}\right]$ and $\left[\mathrm{RuHD}(\mathrm{CO})\left(\mathrm{PPh}_{3}\right)_{3}\right]$ (experiment used for determining the KIE)

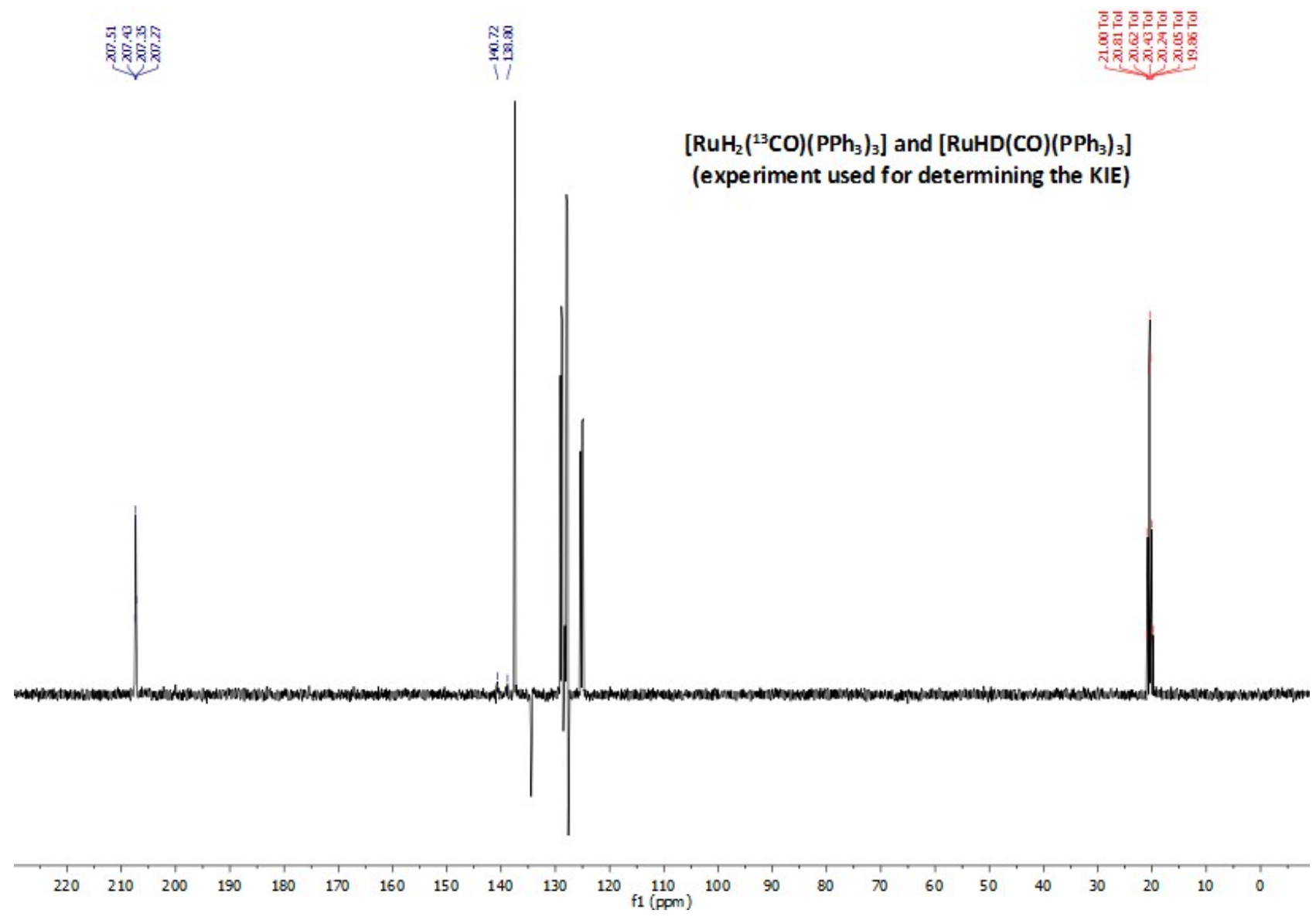

Figure S11 ${ }^{13} \mathrm{C}\left\{{ }^{1} \mathrm{H}\right\}$ NMR (400 MHz; toluene- $\left.d_{8}\right)$ of $\left[\mathrm{RuH}_{2}\left({ }^{13} \mathrm{CO}\right)\left(\mathrm{PPh}_{3}\right)_{3}\right]$ and $\left[\mathrm{RuHD}(\mathrm{CO})\left(\mathrm{PPh}_{3}\right)_{3}\right]$ 


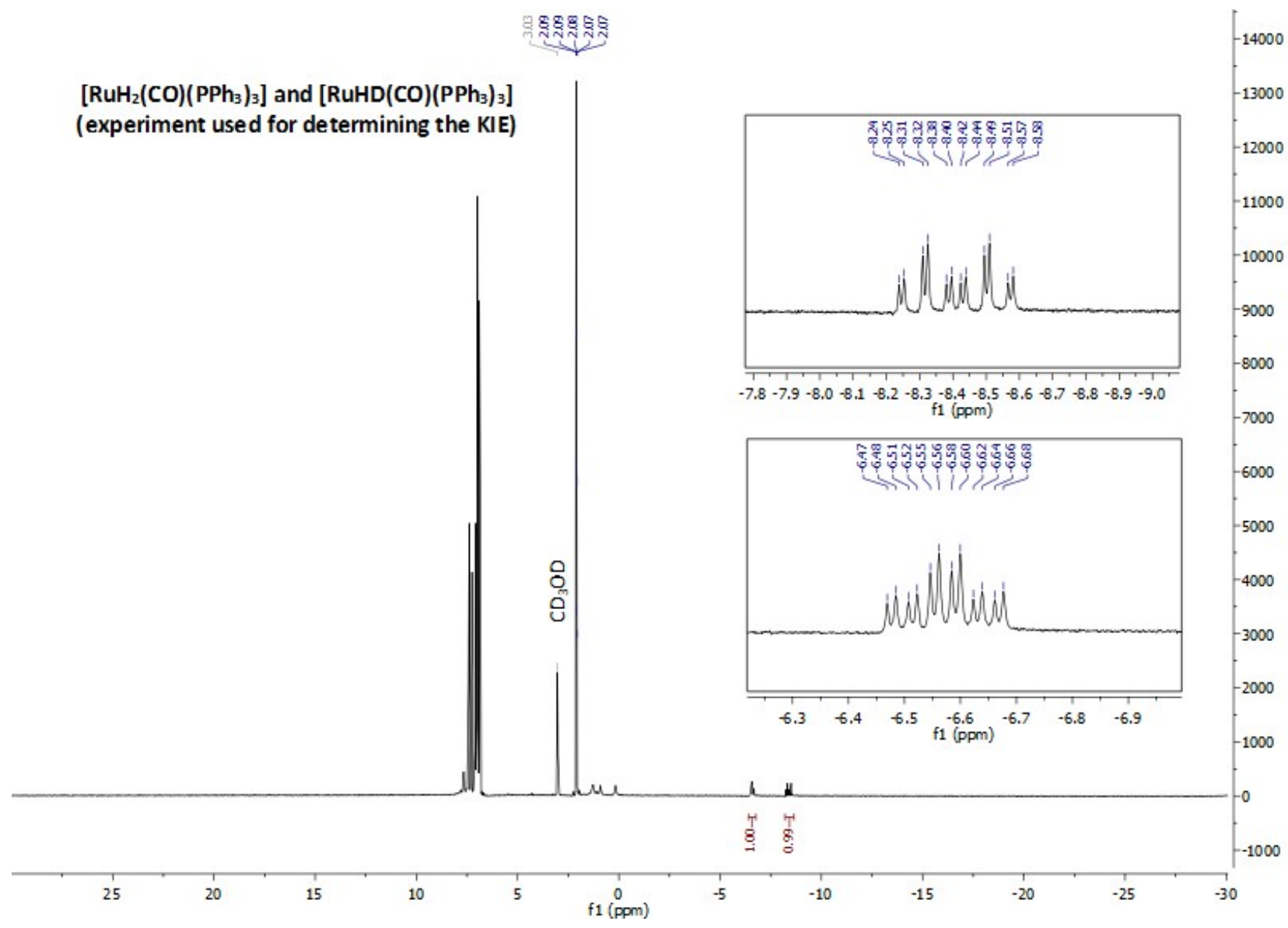

Figure S12 ${ }^{1} \mathrm{H}$ NMR (400 MHz; toluene- $\left.d_{8}\right)$ of $\left[\mathrm{RuH}_{2}(\mathrm{CO})\left(\mathrm{PPh}_{3}\right)_{3}\right]$ and $\left[\mathrm{RuHD}(\mathrm{CO})\left(\mathrm{PPh}_{3}\right)_{3}\right]$ 


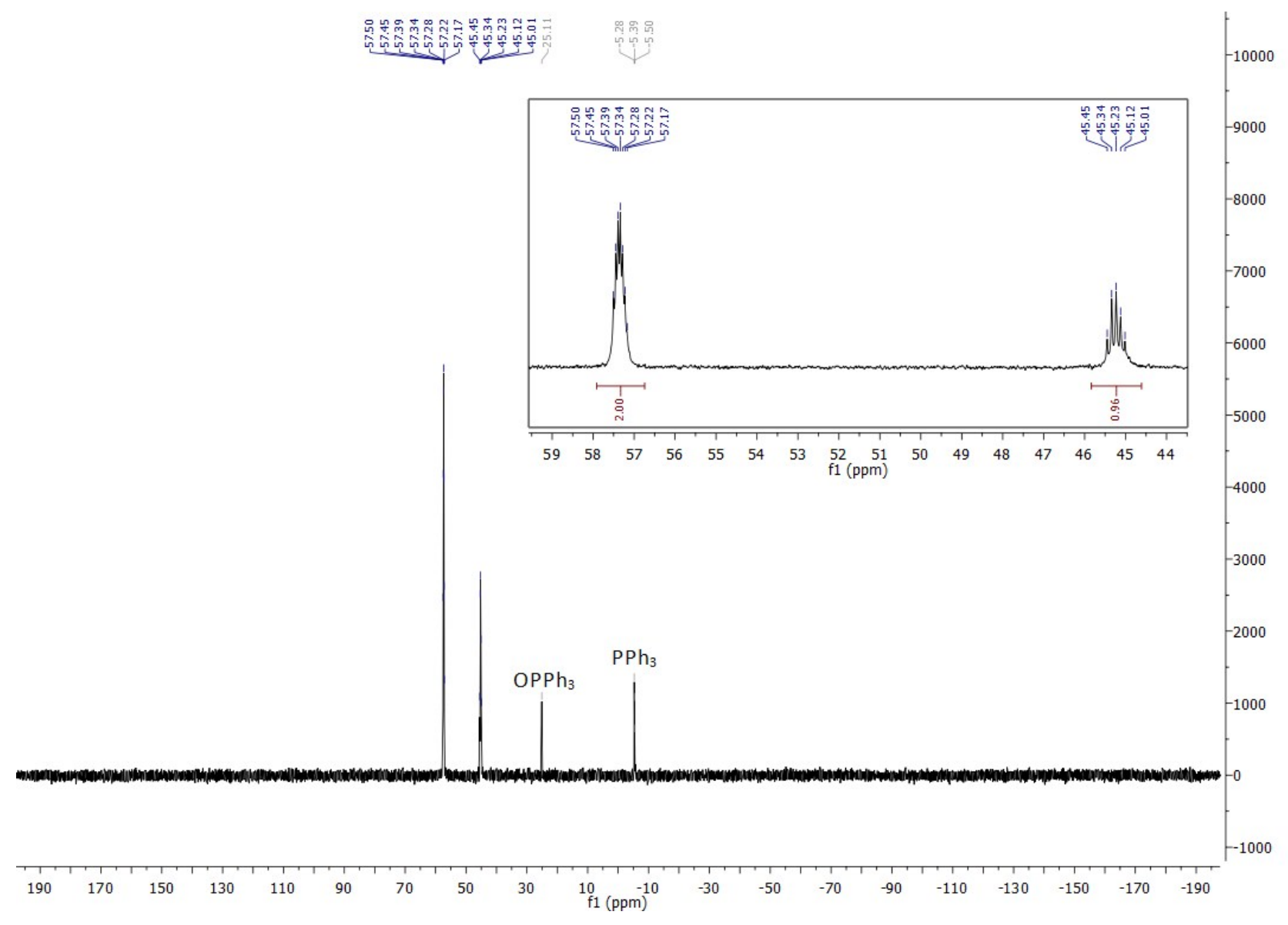

Figure S13 ${ }^{31} \mathrm{P}\left\{{ }^{1} \mathrm{H}\right\} \mathrm{NMR}\left(400 \mathrm{MHz}\right.$; toluene- $\left.d_{8}\right)$ of $\left[\mathrm{RuH}_{2}(\mathrm{CO})\left(\mathrm{PPh}_{3}\right)_{3}\right]$ and $\left[\mathrm{RuHD}(\mathrm{CO})\left(\mathrm{PPh}_{3}\right)_{3}\right]$ 


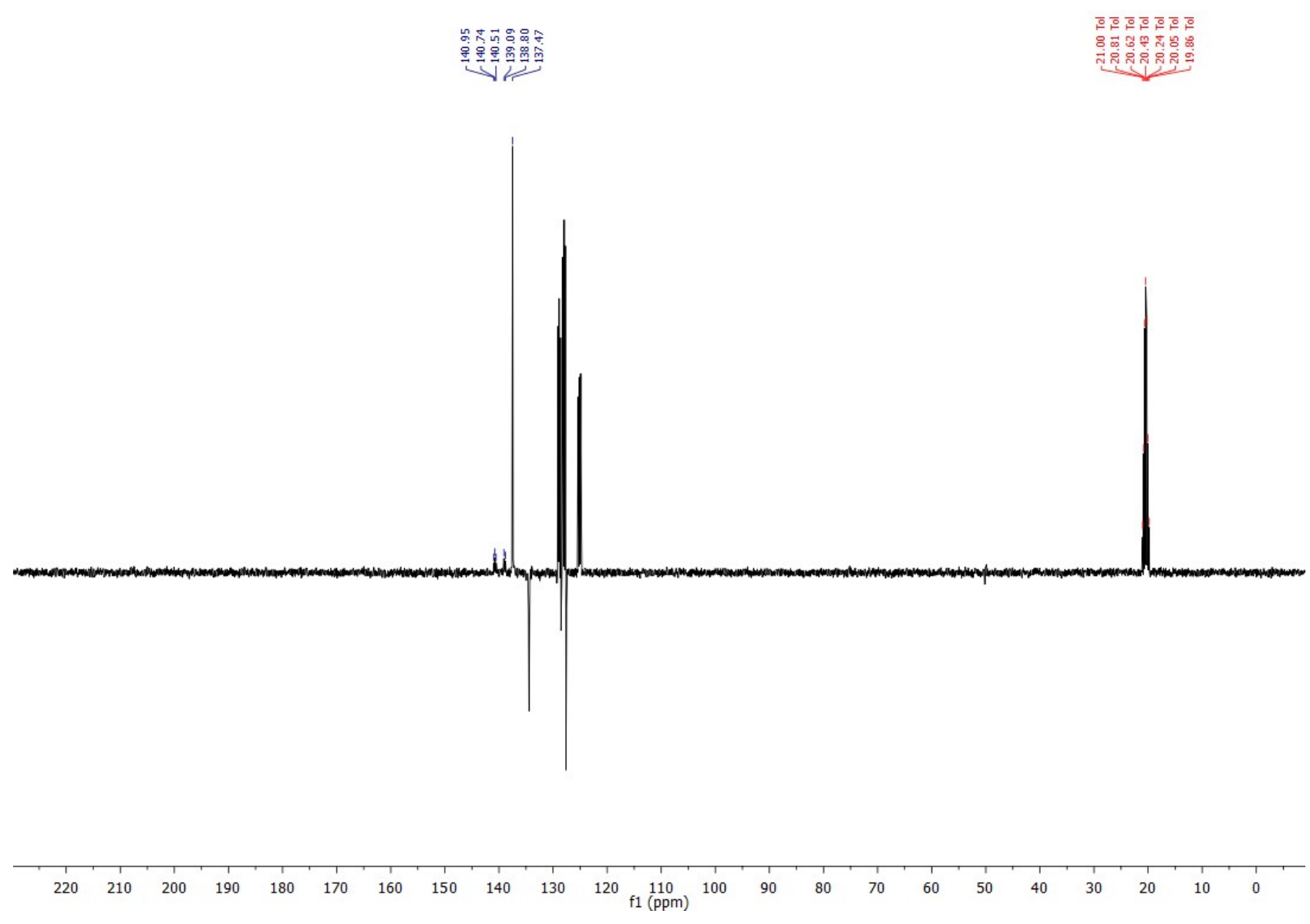

Figure S14 ${ }^{13} \mathrm{C}\left\{{ }^{1} \mathrm{H}\right\}$ NMR (400 MHz; toluene- $\left.d_{8}\right)$ of $\left[\mathrm{RuH}_{2}(\mathrm{CO})\left(\mathrm{PPh}_{3}\right)_{3}\right]$ and $\left[\mathrm{RuHD}(\mathrm{CO})\left(\mathrm{PPh}_{3}\right)_{3}\right]$ 
1.7 Time and temperature dependent NMR studies with $\mathrm{NaOCD}_{3}$

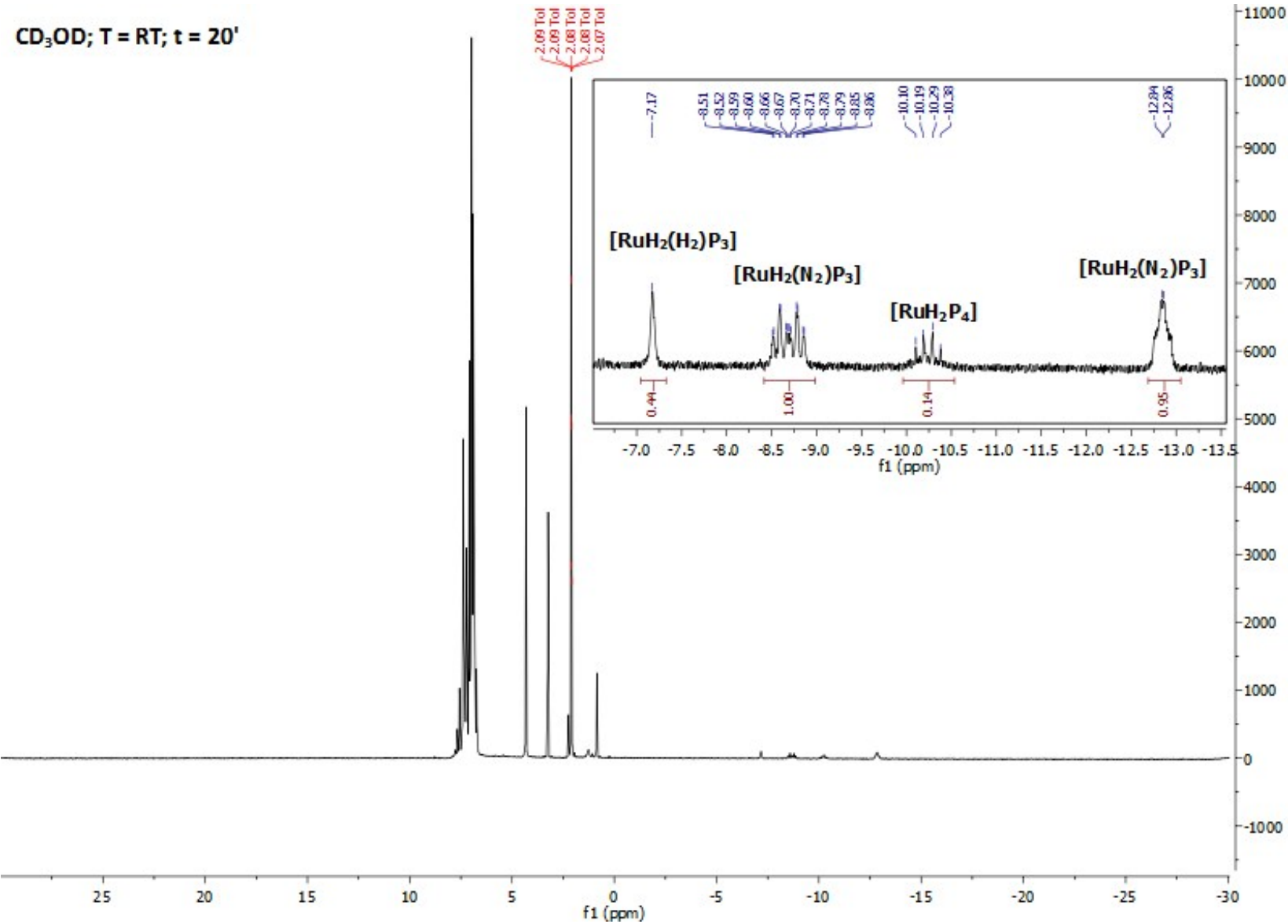

Figure S15 ${ }^{1} \mathrm{H}$ NMR (400 MHz; toluene- $d_{8}$ ); First step: 20 min at RT 


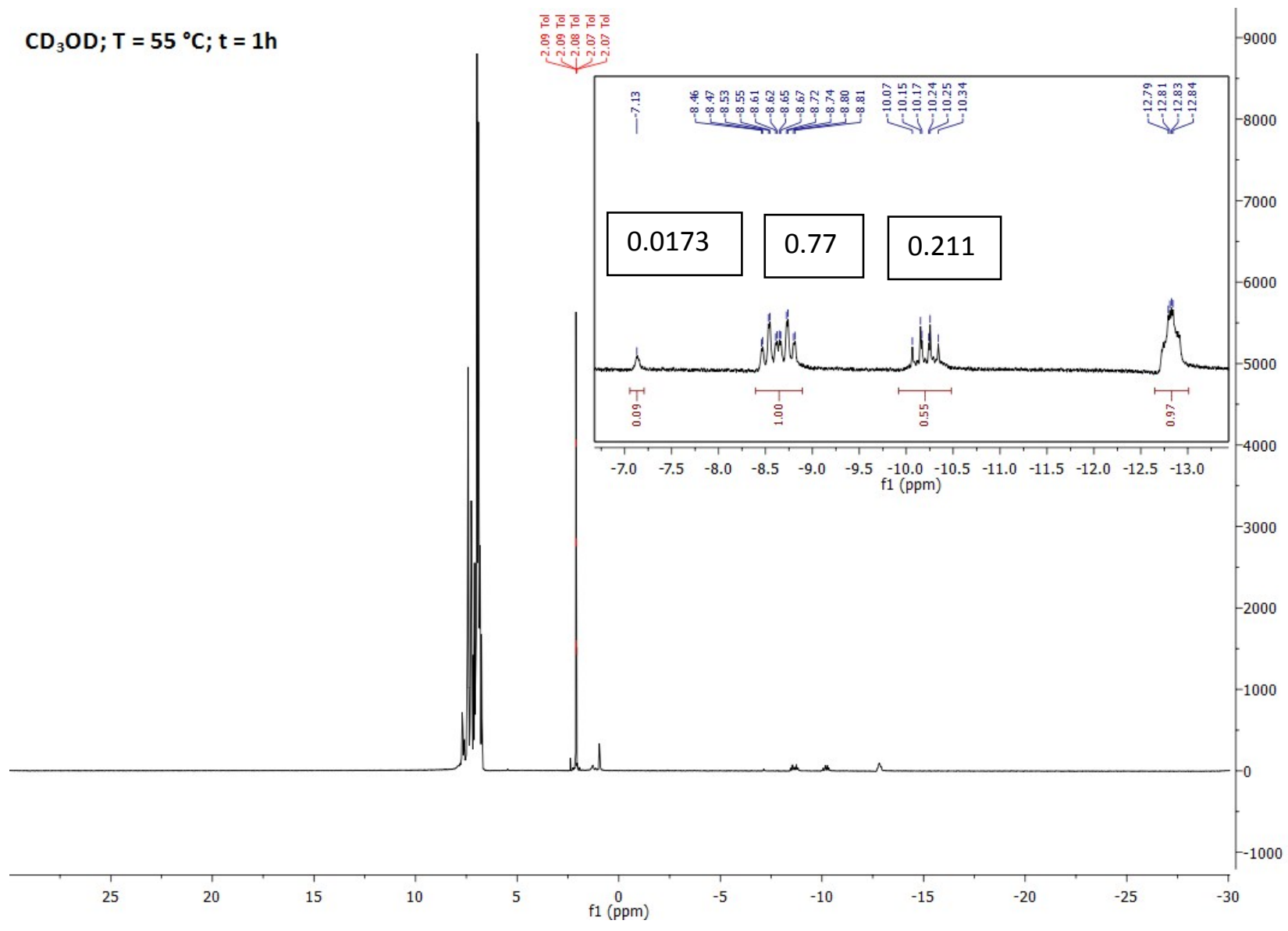

Figure $\mathrm{S} 16{ }^{1} \mathrm{H}$ NMR (400 MHz; toluene- $d_{8}$ ); Second step: 40 min at $55{ }^{\circ} \mathrm{C}$. 


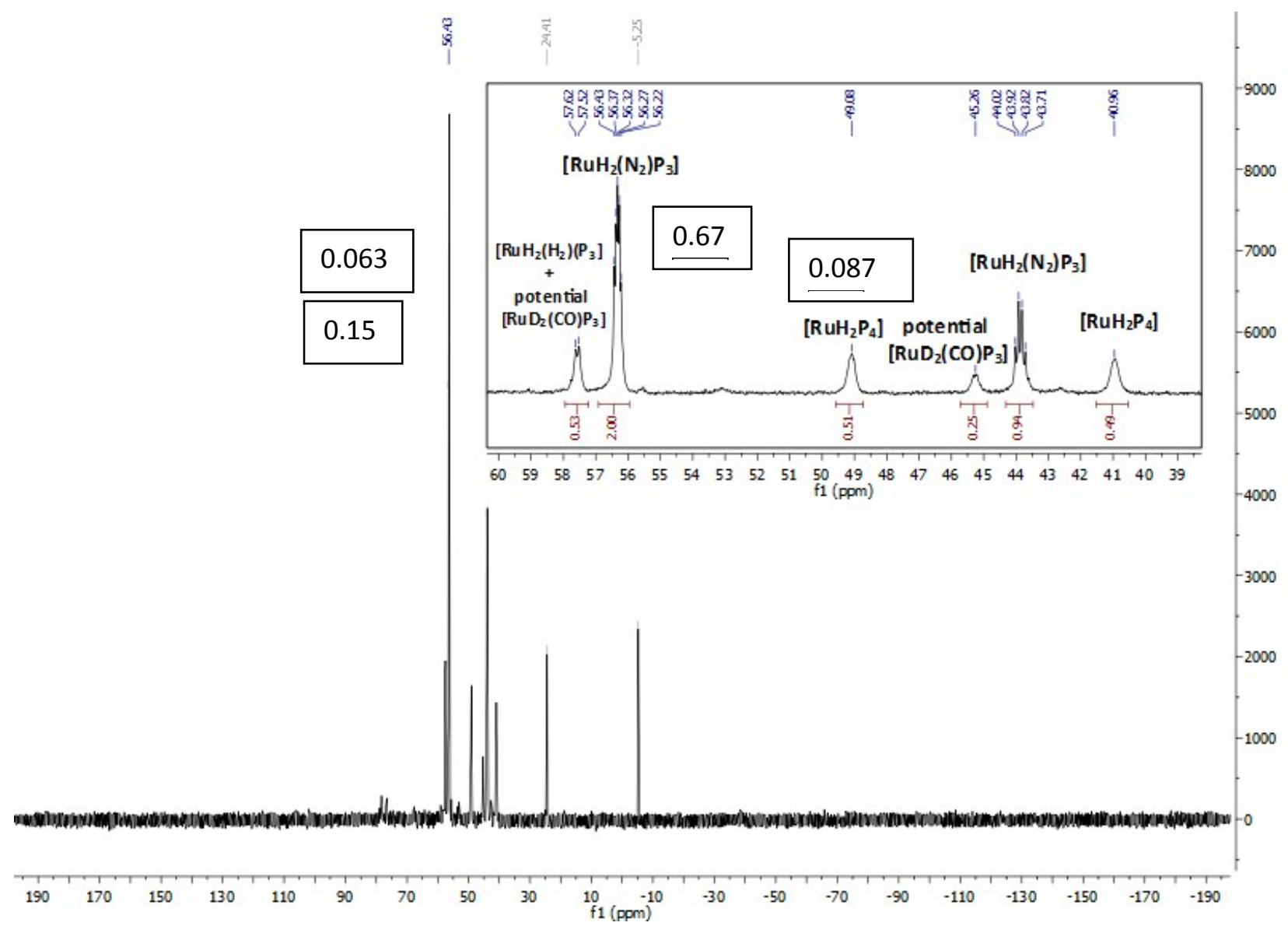

Figure S17 ${ }^{31} \mathrm{P}\left\{{ }^{1} \mathrm{H}\right\}$ NMR (400 MHz; toluene- $d_{8}$ ); Second step: $40 \mathrm{~min}$ at $55^{\circ} \mathrm{C}$. 


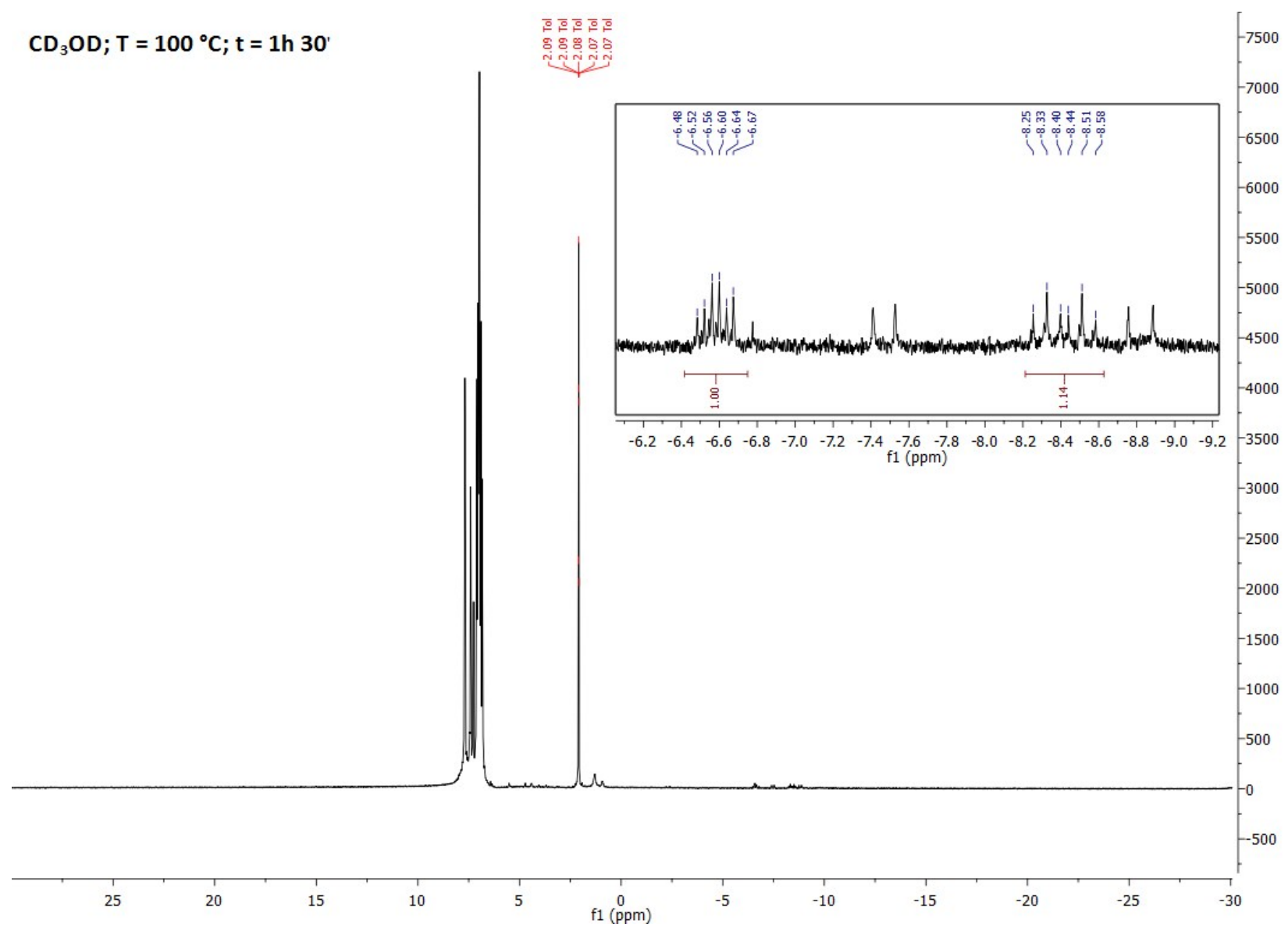

Figure S18 ${ }^{1} \mathrm{H}$ NMR (400 MHz; toluene- $d_{8}$ ); Third step: $30 \mathrm{~min}$ at $100{ }^{\circ} \mathrm{C}$. 


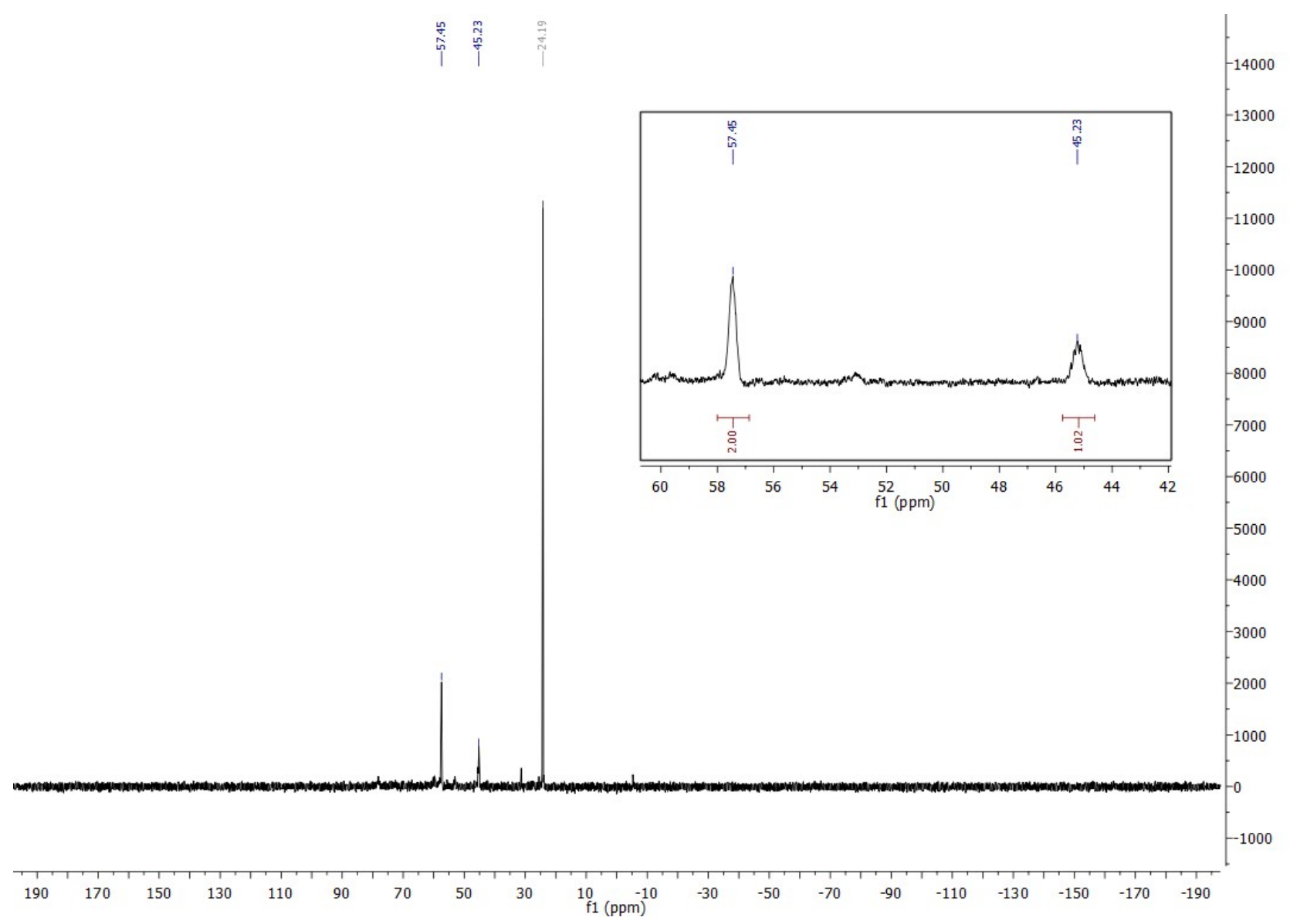

Figure S19 ${ }^{31} \mathrm{P}\left\{{ }^{1} \mathrm{H}\right\} \mathrm{NMR}\left(400 \mathrm{MHz}\right.$; toluene- $\left.d_{8}\right)$; Third step: $30 \mathrm{~min}$ at $100{ }^{\circ} \mathrm{C}$. 


\subsection{Time and temperature dependent NMR studies with $\mathrm{NaOCH}_{3}$}

$\mathrm{CH}_{3} \mathrm{OH} ; \mathrm{T}=\mathrm{RT}$; $\mathrm{t}=15^{\prime}$

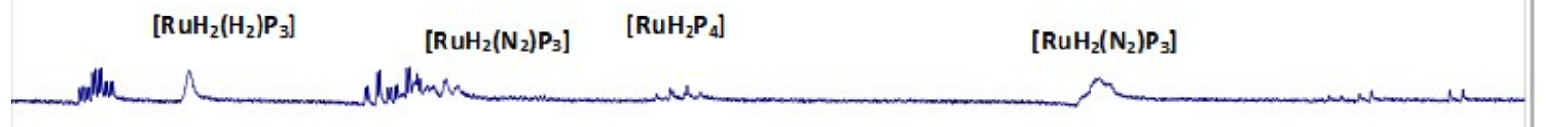

$\mathrm{CH}_{3} \mathrm{OH} ; \mathrm{T}=55^{\circ} \mathrm{C} ; \mathrm{t}=45^{\prime}$

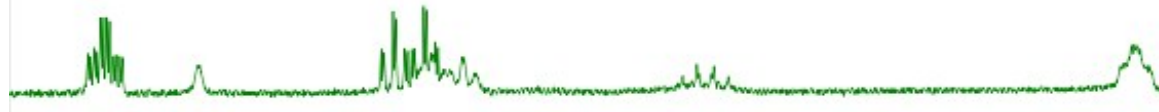

$\mathrm{CH}_{3} \mathrm{OH} ; \mathrm{T}=100^{\circ} \mathrm{C} ; \mathrm{t}=1 \mathrm{~h} 15^{\prime}$

$\left[\mathrm{RuH}_{2}(\mathrm{CO})\left(\mathrm{PPh}_{3}\right)_{3}\right]$
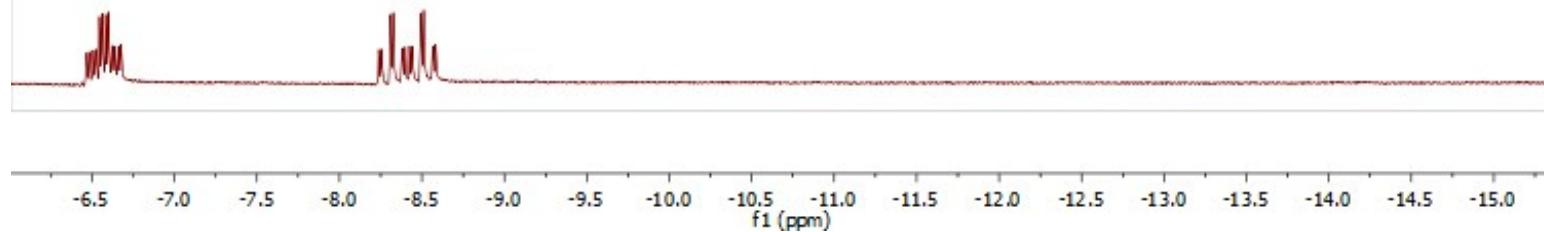

Figure S20 ${ }^{1} \mathrm{H}$ NMR (400 MHz; toluene- $d_{8}$ ). Time and temperature dependent ${ }^{1} \mathrm{H}$ NMR study of $\left[\mathrm{RuHCl} \mathrm{P}_{3}\right]$ with $\mathrm{NaOCH}_{3}$ : hydride region of the reaction mixture. 
(a) $\left[\mathrm{RuH}_{2}(\mathrm{CO})\left(\mathrm{PPh}_{3}\right)_{3}\right]$

(b) $\left[\mathrm{RuH}_{2}\left(\mathrm{H}_{2}\right)\left(\mathrm{PPh}_{3}\right)_{3}\right]$

(c) $\left[\mathrm{RuH}_{2}\left(\mathrm{~N}_{2}\right)\left(\mathrm{PPh}_{3}\right)_{3}\right]$

(d) $\left[\mathrm{RuH}_{2}\left(\mathrm{PPh}_{3}\right)_{4}\right]$

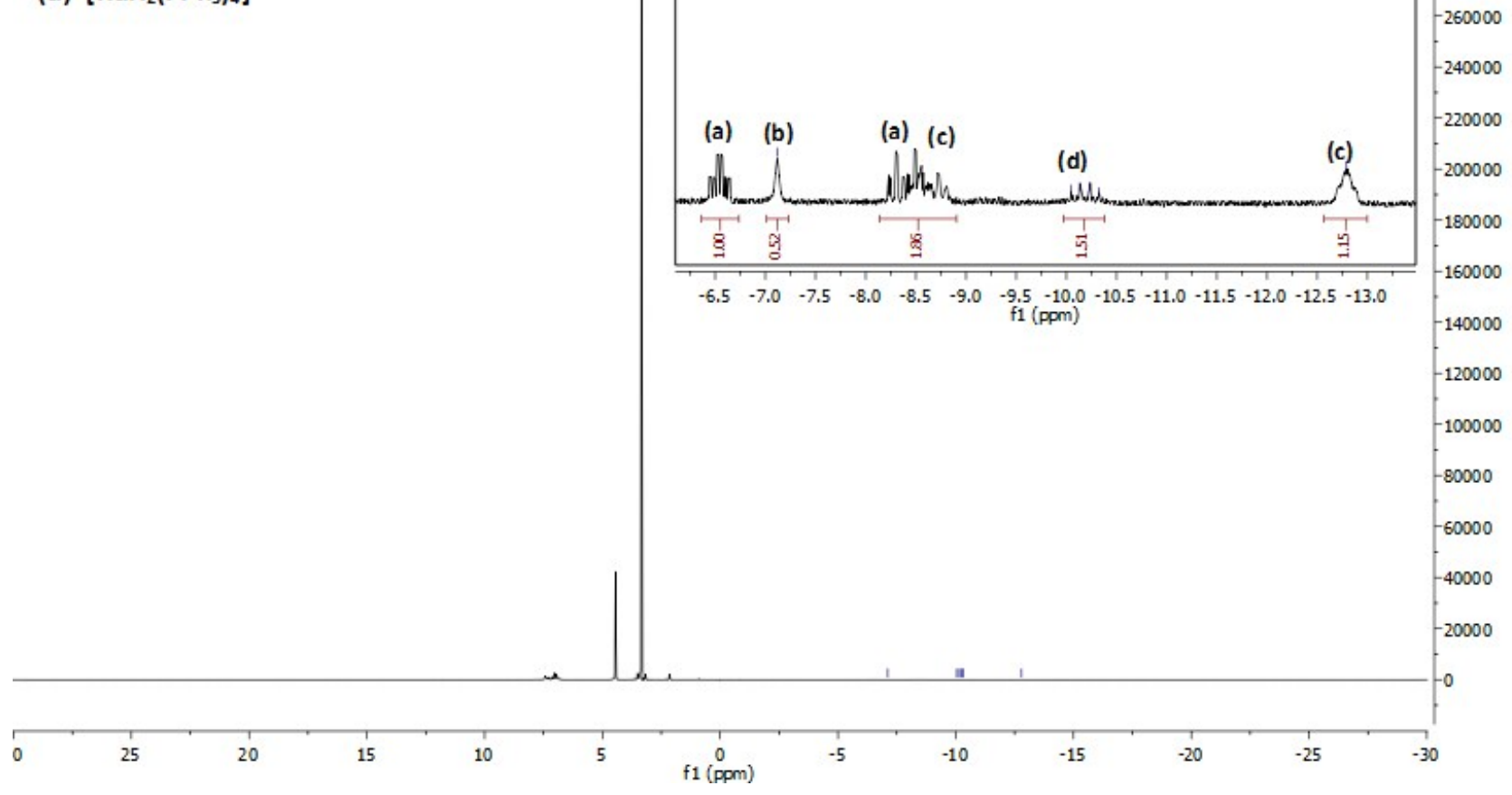

Figure S21 ${ }^{1} \mathrm{H}$ NMR (400 MHz; toluene- $d_{8}$ ); First step: 15 min at RT. 


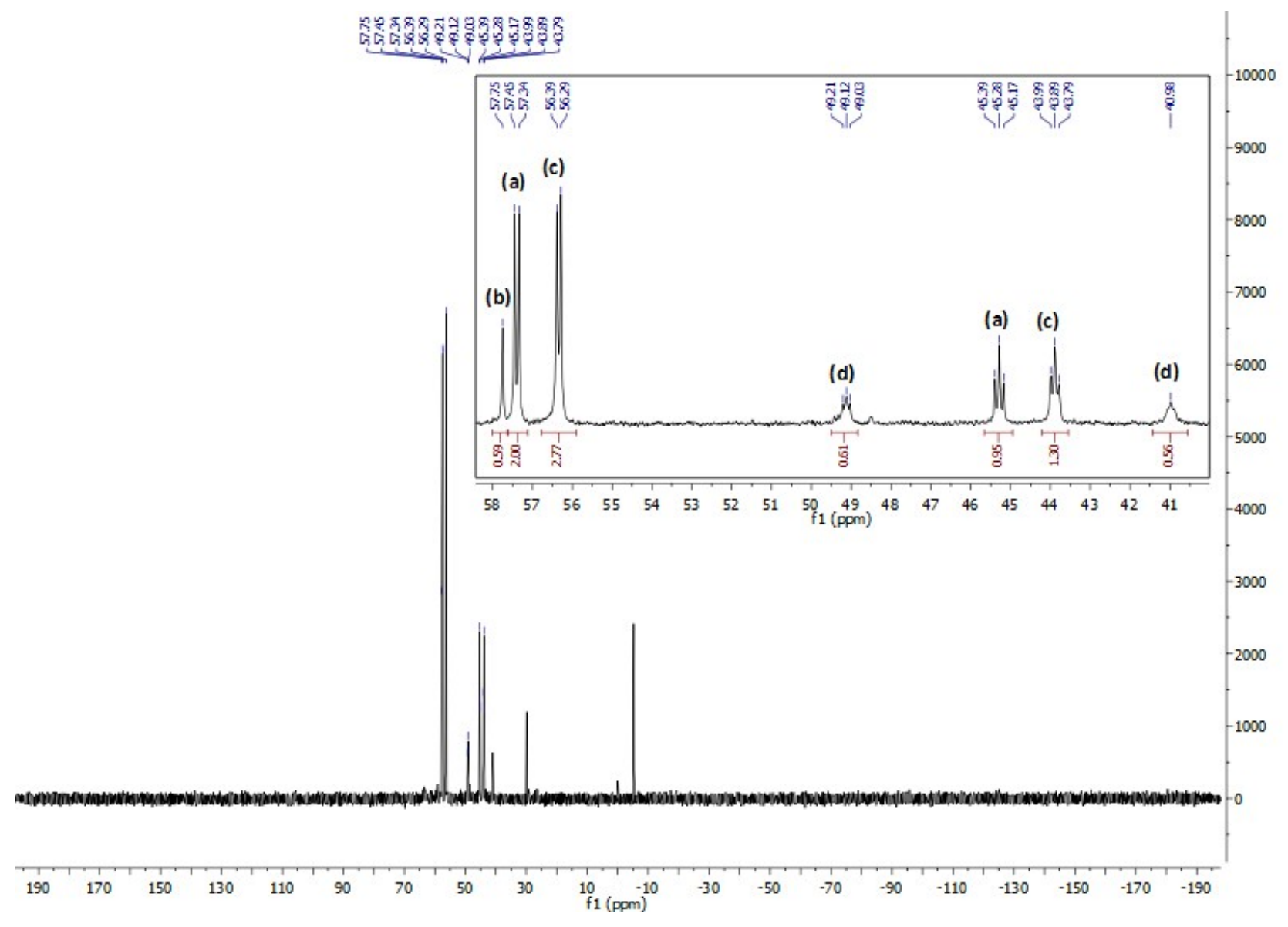

Figure S22 ${ }^{31} \mathrm{P}\left\{{ }^{1} \mathrm{H}\right\} \mathrm{NMR}\left(400 \mathrm{MHz}\right.$; toluene- $\left.d_{8}\right)$; First step: $15 \mathrm{~min}$ at RT. 


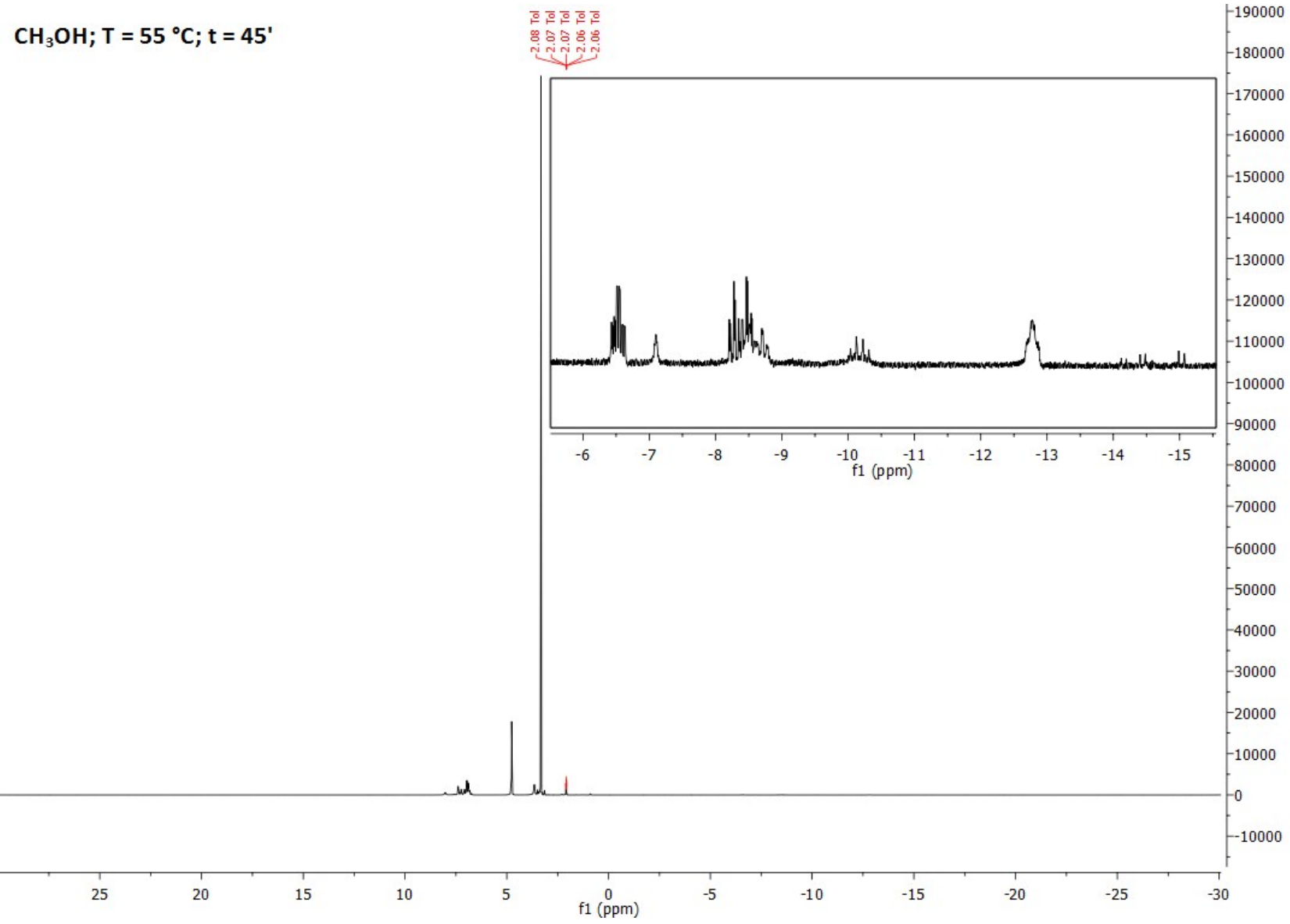

Figure S23 ${ }^{1} \mathrm{H}$ NMR (400 MHz; toluene- $d_{8}$ ); Second step: 30 min at $55^{\circ} \mathrm{C}$. 


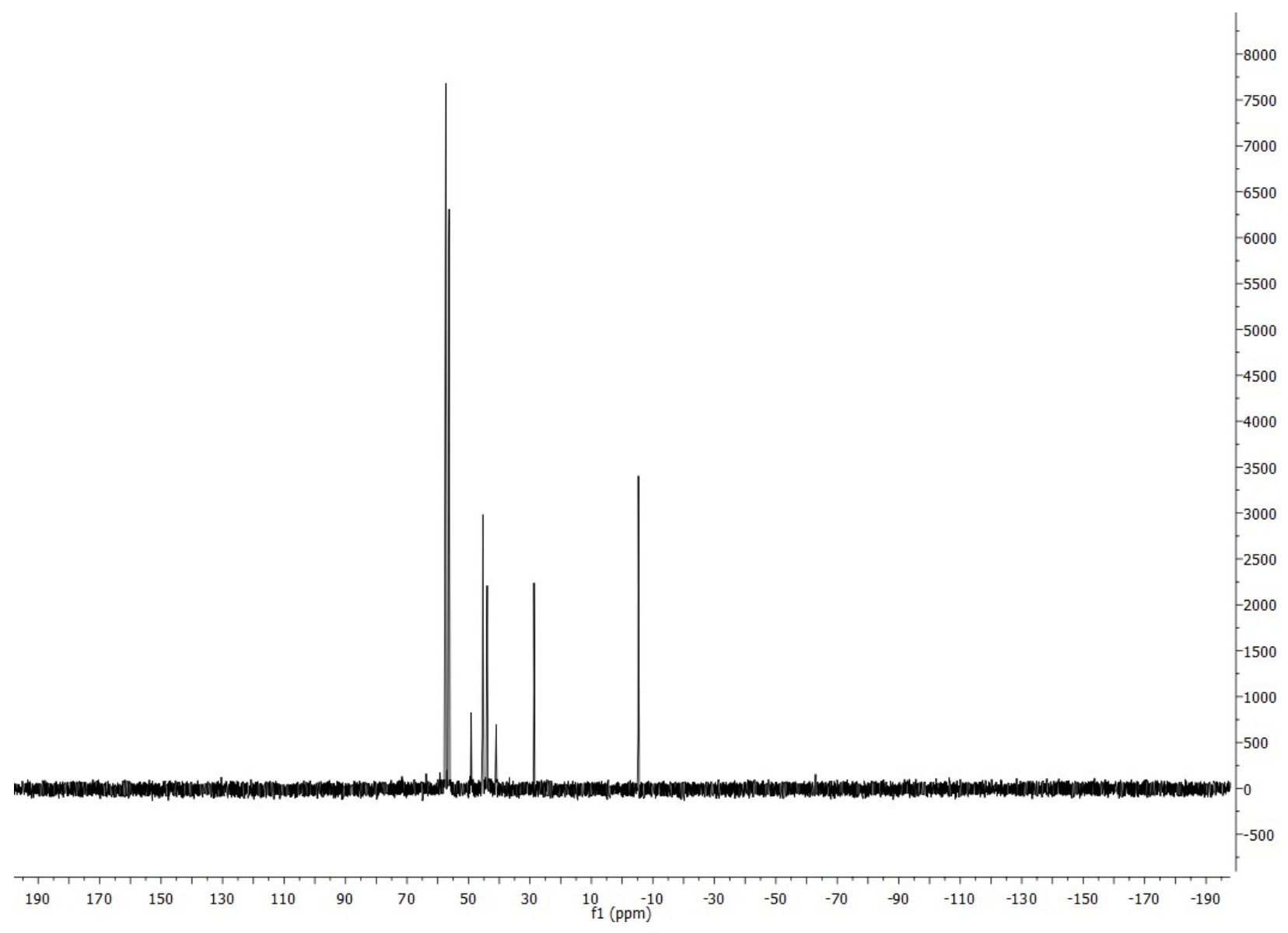

Figure S24 ${ }^{31} \mathrm{P}\left\{{ }^{1} \mathrm{H}\right\} \mathrm{NMR}\left(400 \mathrm{MHz}\right.$; toluene- $\left.d_{8}\right)$; Second step: 30 min at $55{ }^{\circ} \mathrm{C}$. 


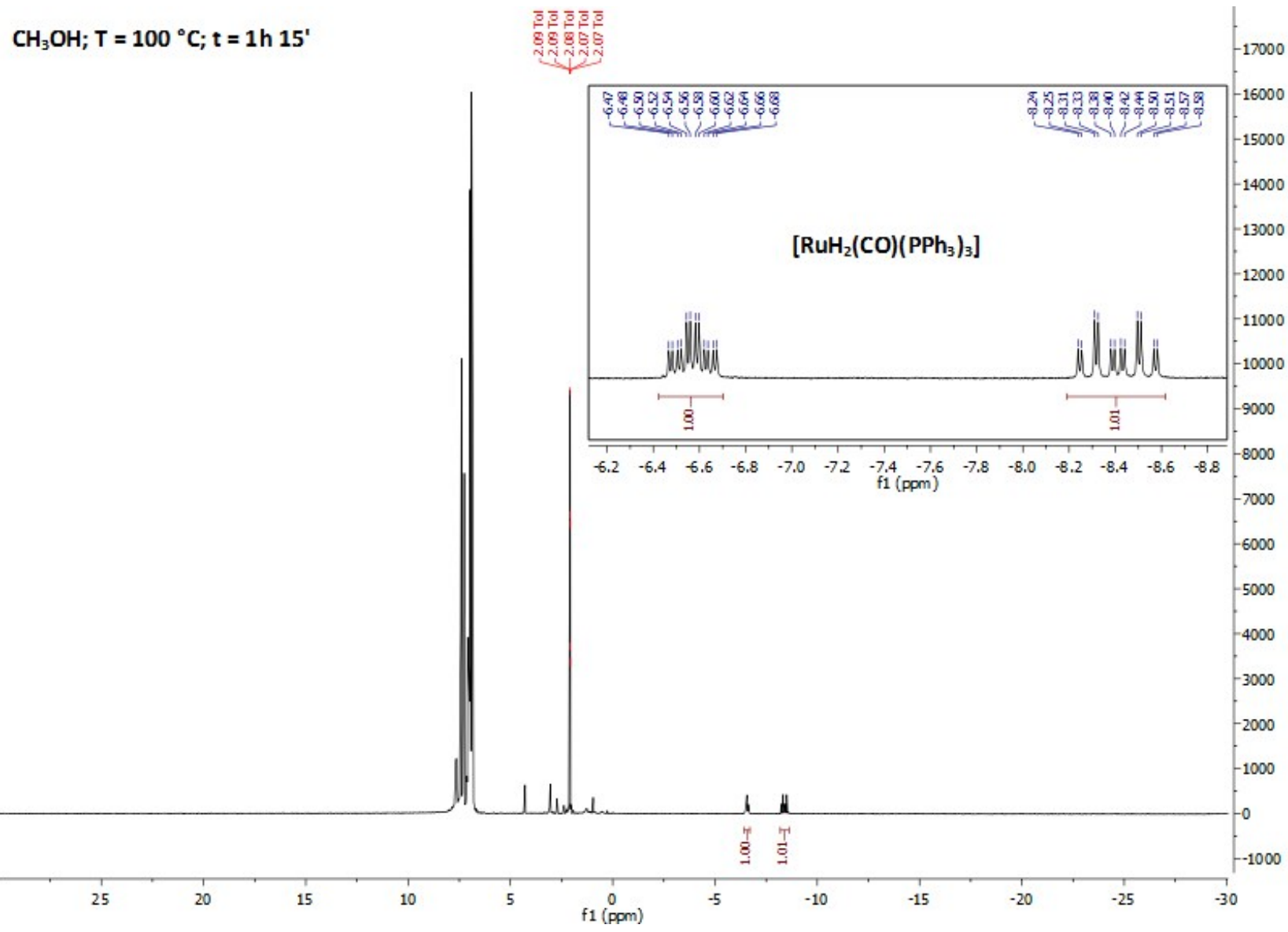

Figure S25 ${ }^{1} \mathrm{H}$ NMR (400 MHz; toluene- $d_{8}$ ); Third step: $30 \mathrm{~min}$ at $100{ }^{\circ} \mathrm{C}$. 


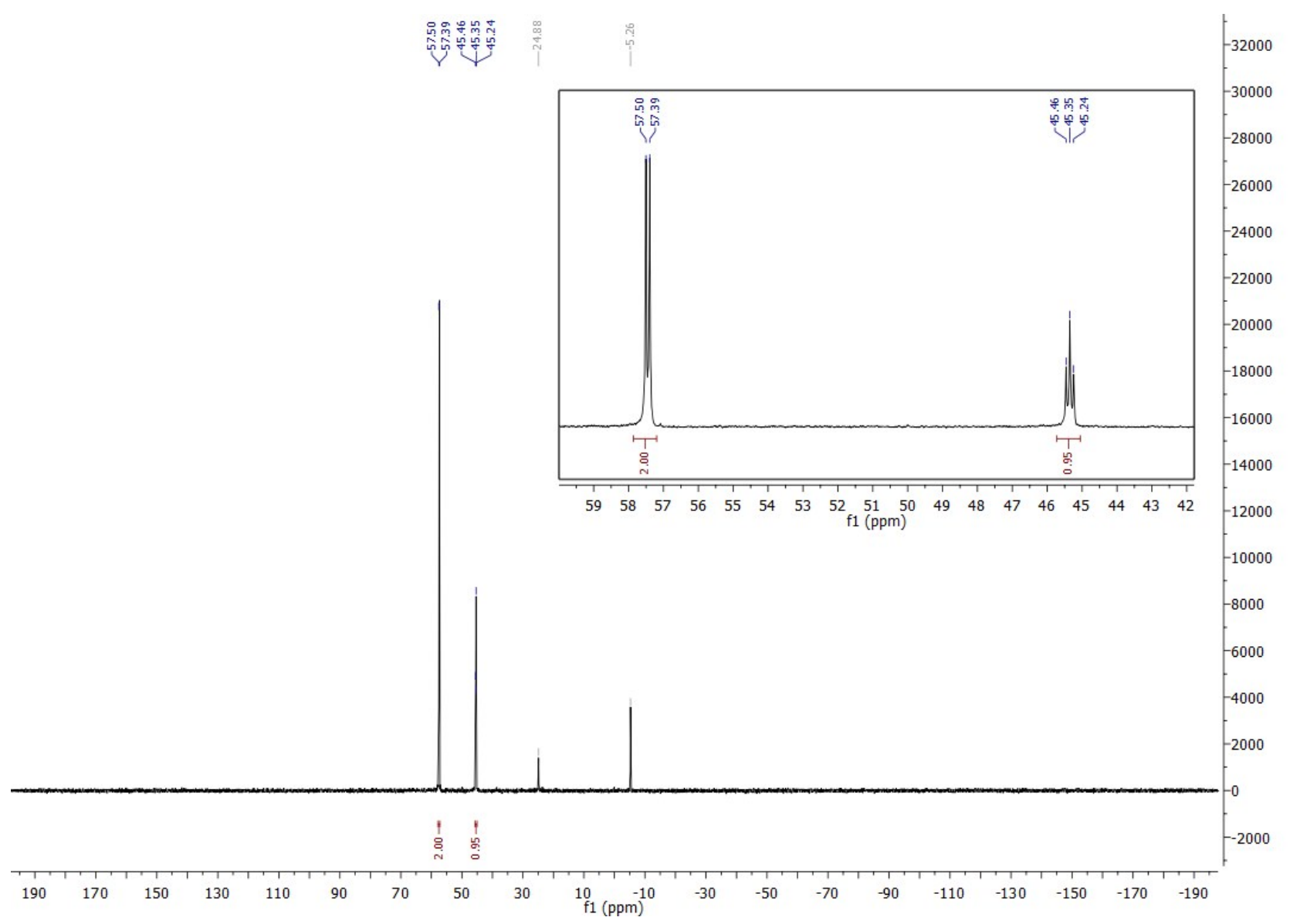

Figure S26 ${ }^{31} \mathrm{P}\left\{{ }^{1} \mathrm{H}\right\} \mathrm{NMR}\left(400 \mathrm{MHz}\right.$; toluene- $\left.d_{8}\right)$; Third step: $30 \mathrm{~min}$ at $100{ }^{\circ} \mathrm{C}$. 


\subsection{Identification of $\left[\mathrm{RuH}_{2}\left(\mathrm{~N}_{2}\right)\left(\mathrm{PPh}_{3}\right)_{3}\right]$}

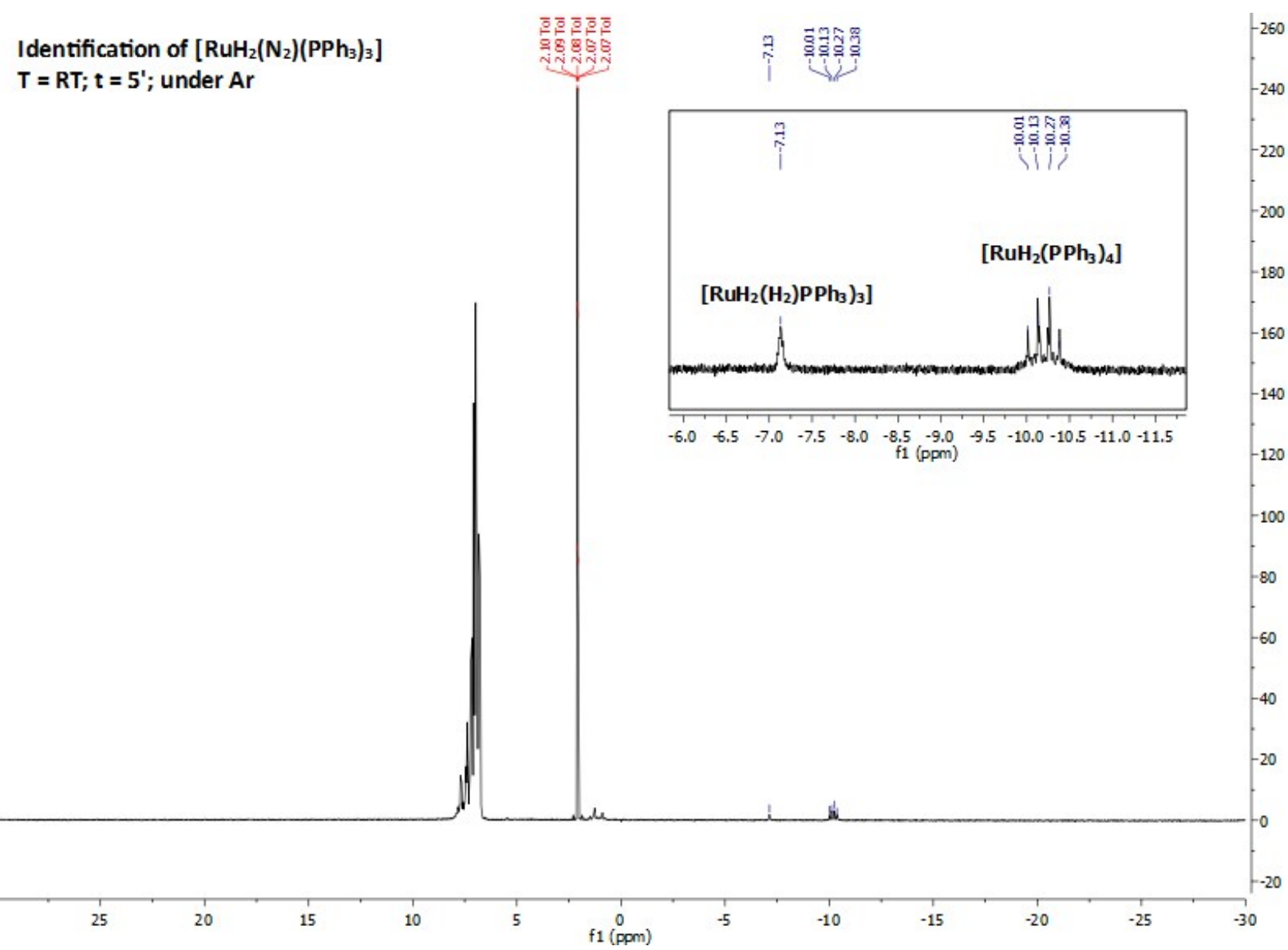

Figure S27 ${ }^{1} \mathrm{H}$ NMR (300 MHz; toluene- $\left.d_{8}\right)$; Identification of $\left[\mathrm{RuH}_{2}\left(\mathrm{~N}_{2}\right)\left(\mathrm{PPh}_{3}\right)_{3}\right]$ by performing the reaction under Ar. 


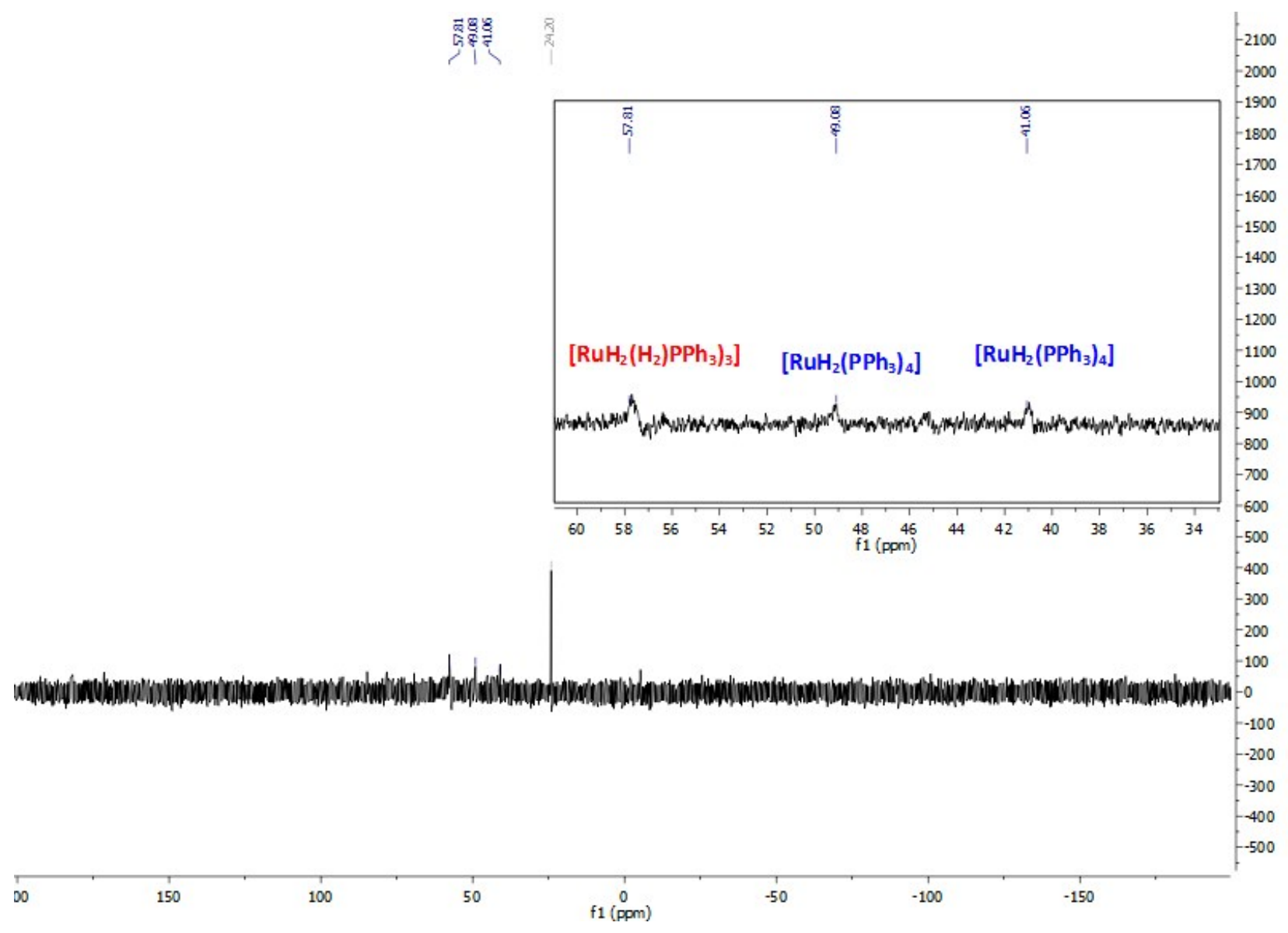

Figure S28 ${ }^{31} \mathrm{P}\left\{{ }^{1} \mathrm{H}\right\} \mathrm{NMR}\left(300 \mathrm{MHz}\right.$; toluene- $\left.d_{8}\right)$; Identification of $\left[\mathrm{RuH}_{2}\left(\mathrm{~N}_{2}\right)\left(\mathrm{PPh}_{3}\right)_{3}\right]$ by performing the reaction under Ar. 


\subsection{Identification of $\left[\mathrm{RuH}_{2}\left(\mathrm{PPh}_{3}\right)_{4}\right]$}

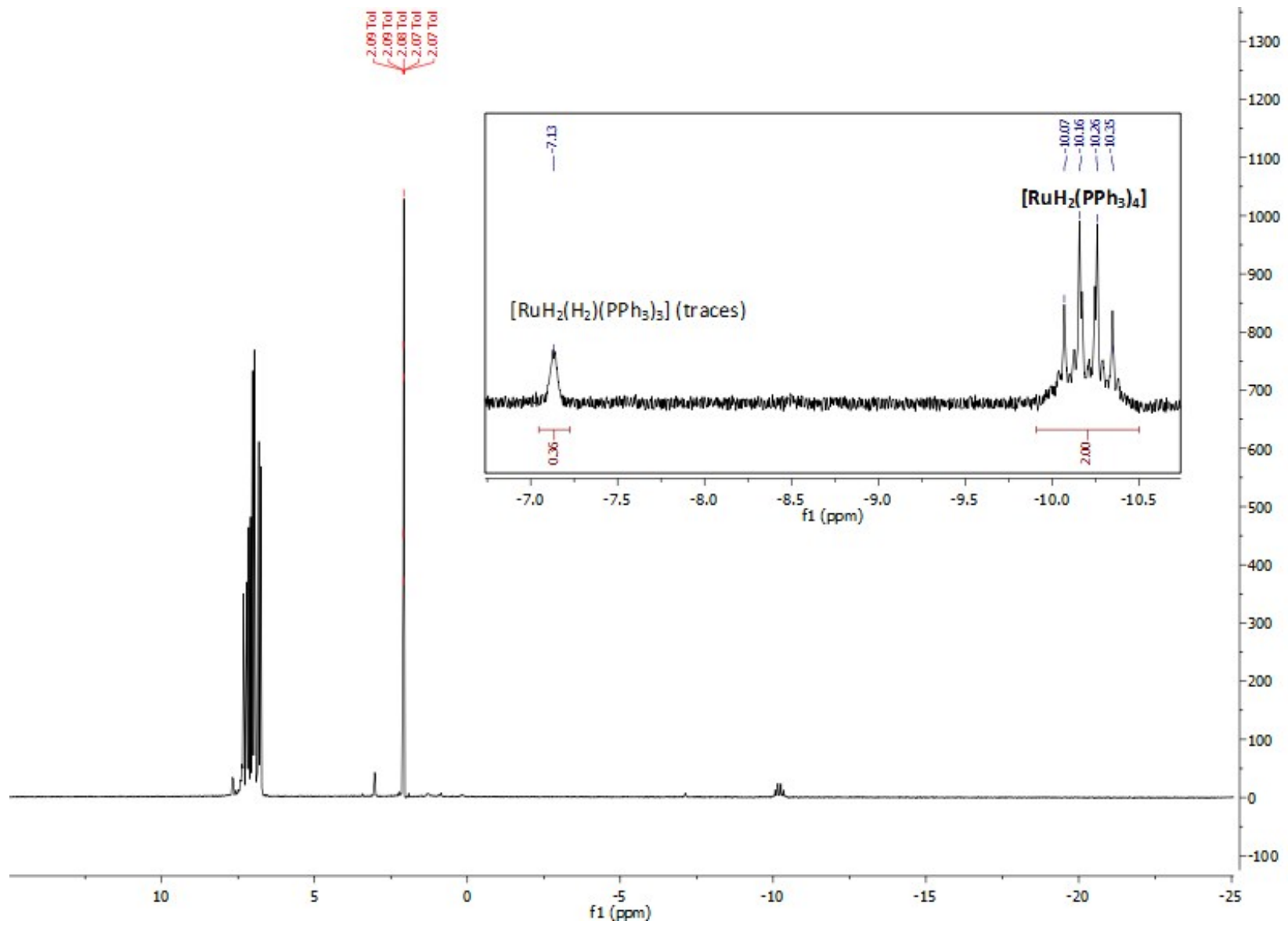

Figure $\mathbf{S 2 9}{ }^{1} \mathrm{H}$ NMR $\left(400 \mathrm{MHz}\right.$; toluene- $\left.d_{8}\right)$ of $\left[\mathrm{RuH}_{2}\left(\mathrm{PPh}_{3}\right)_{4}\right]$ 


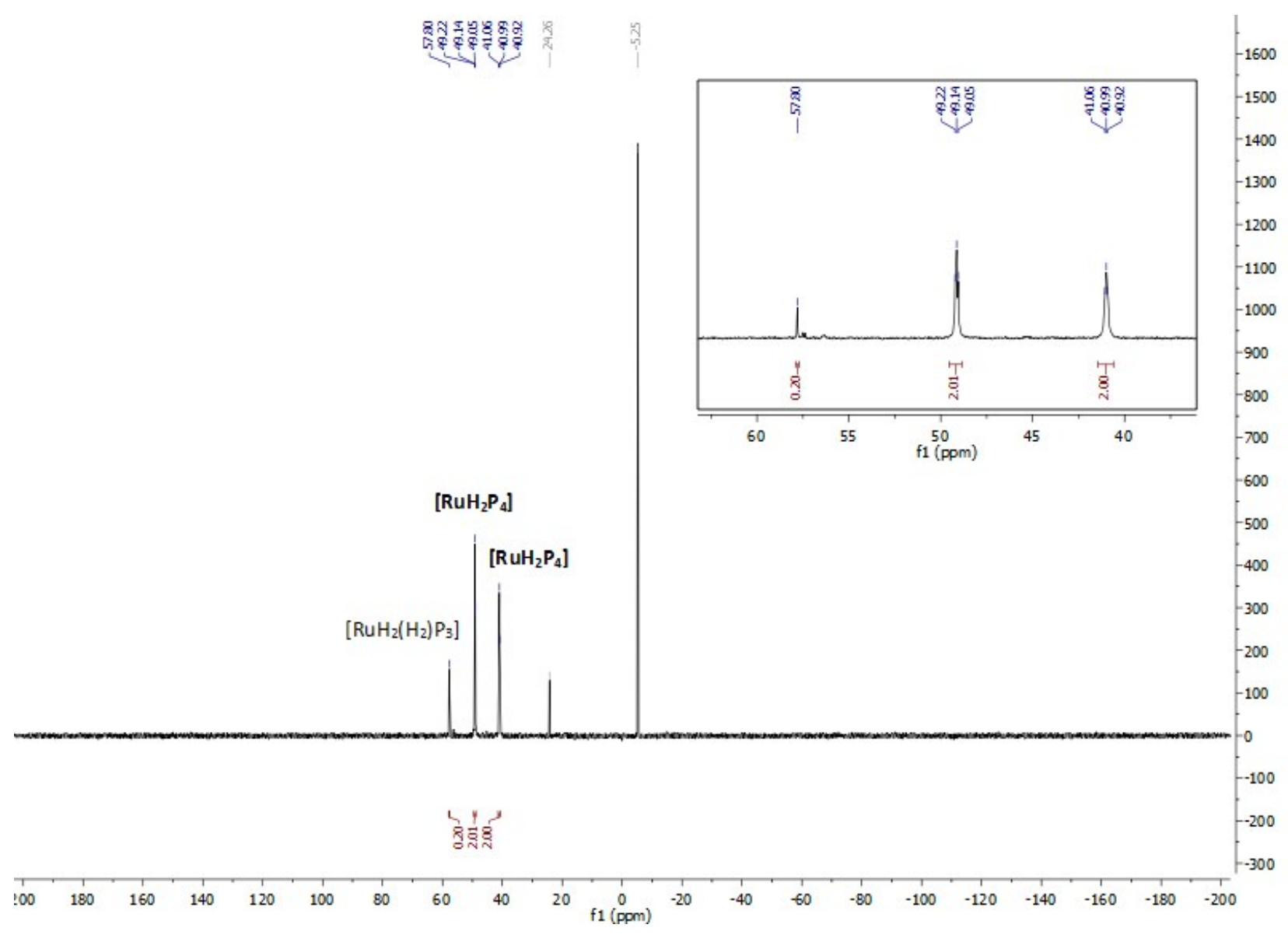

Figure S30 ${ }^{31} \mathrm{P}\left\{{ }^{1} \mathrm{H}\right\} \mathrm{NMR}\left(400 \mathrm{MHz}\right.$; toluene- $\left.d_{8}\right)$ of $\left[\mathrm{RuH}_{2}\left(\mathrm{PPh}_{3}\right)_{4}\right]$ 
2 Evidence for $o$-D incorporation into coordinated $\mathrm{PPh}_{3}$
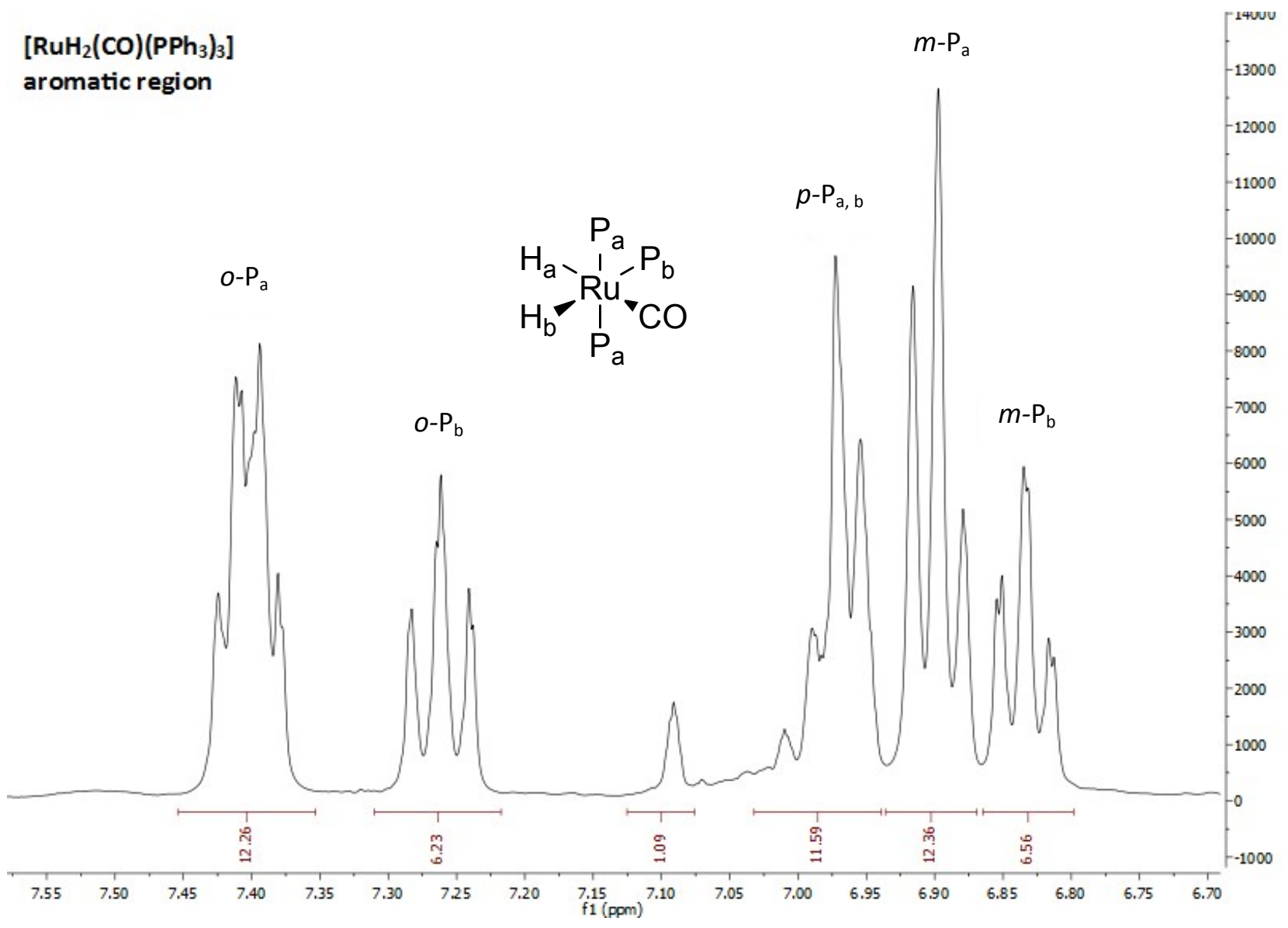

Figure S31 ${ }^{1} \mathrm{H}$ NMR $\left(400 \mathrm{MHz}\right.$; toluene- $\left.d_{8}\right)$; aromatic region of $\left[\mathrm{RuH}_{2}(\mathrm{CO})\left(\mathrm{PPh}_{3}\right)_{3}\right]$. The integration of the Ru$\mathrm{H}$ signals was set at 1.0 for each 


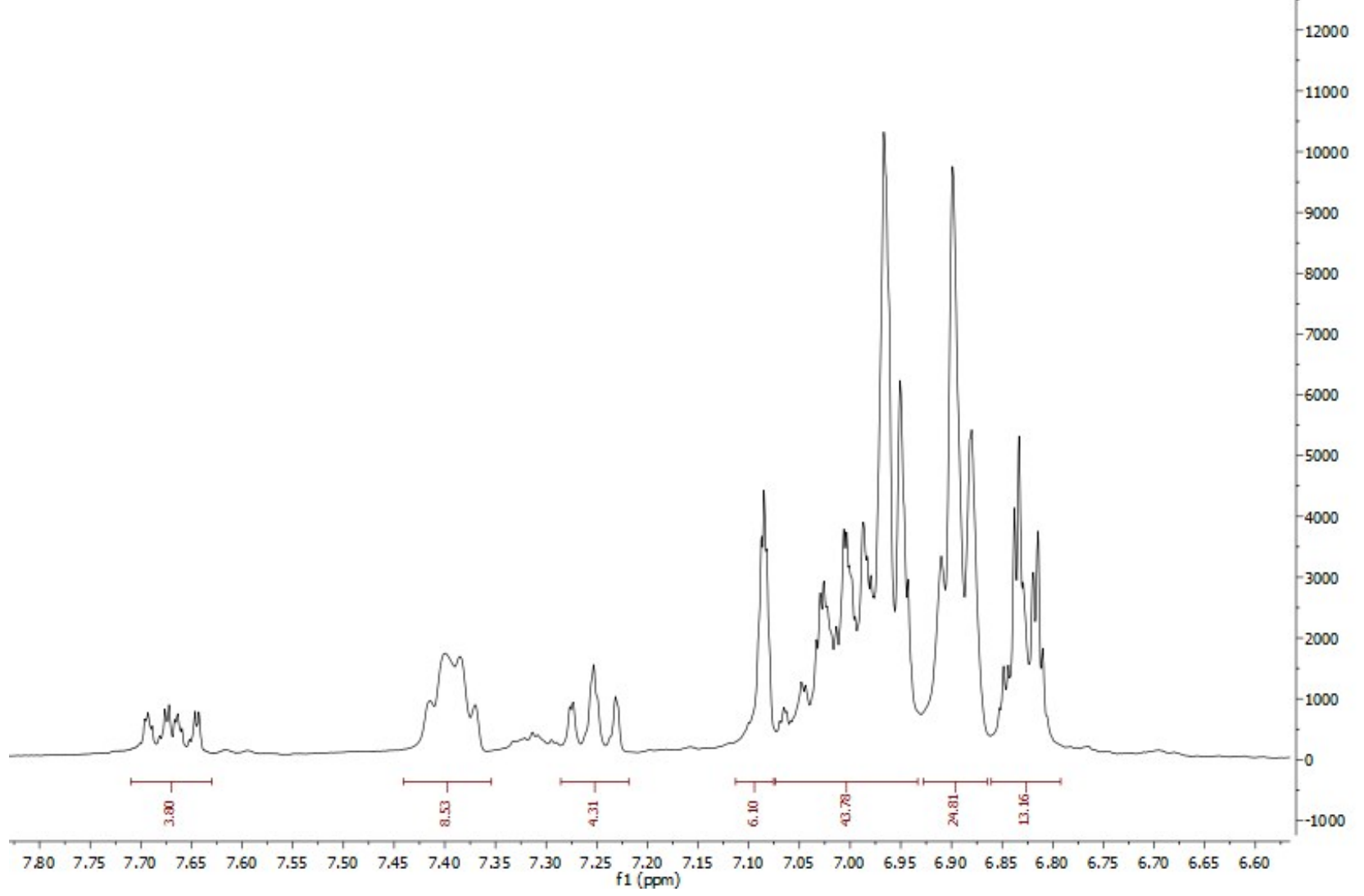

Figure S32 ${ }^{1} \mathrm{H}$ NMR (400 MHz; toluene- $\left.d_{8}\right)$; aromatic region of $\left[\mathrm{RuHD}(\mathrm{CO})\left(\mathrm{PPh}_{3}\right)_{3}\right]$ (2 isomers) and $\left[\mathrm{RuH}_{2}(\mathrm{CO})\left(\mathrm{PPh}_{3}\right)_{3}\right]$ (minor species). The Ru-H resonances were of the same intensity, which was set at 1 .

The formation of $\left[\mathrm{RuH}_{4} \mathrm{P}_{3}{ }_{3}\right]$ the reaction of $\left[\mathrm{RuHClP}_{3}\right]$ and $\mathrm{CD}_{3} \mathrm{OD} / \mathrm{Na}$ requires that $\mathrm{H} / \mathrm{D}$ exchange occurs inti the aromatic rings of the coordinated phosphines, as previously observed by Halpern and co-workers. Some evidence that this is occurring is discussed in the main paper with signals being observed in the ${ }^{2} \mathrm{H} N \mathrm{NM}$ spectrum corresponding to deuteration in the ortho positions of both $\mathrm{P}_{\mathrm{a}}$ and $\mathrm{P}_{\mathrm{b}}$, broadening of the ${ }^{31} \mathrm{P} N M R$ signals and evidence for incorporation of $\mathrm{D}$ into $\mathrm{PPh}_{3}$ and $\mathrm{Ph}_{3} \mathrm{PO}$ from the ${ }^{31} \mathrm{P} N \mathrm{NMR}$ spectra ( $\beta$-shifted resonances. In order to try to obtain quantitative data on the extent of incorporation, we have analysed the aromatic region of the ${ }^{1} \mathrm{H}$ NMR spectra of the final products obtained from the reaction of $\left[\mathrm{RuHClP}_{3}\right]$ with $\mathrm{MeOH} / \mathrm{Na}$ and with $\mathrm{CD}_{3} \mathrm{OD} / \mathrm{Na}$. For the reaction using $\mathrm{MeOH}$ (Figure S31), the ortho and meta protons from $\mathrm{P}_{\mathrm{a}}$ and $\mathrm{P}_{\mathrm{b}}$ give well separated signals, whilst the para protons resonate in the same place. The $o$ and $m$ protons do not overlap with signals from $\mathrm{PPh}_{3}$ or $\mathrm{Ph}_{3} \mathrm{PO}$, although the $p$ protons do.

Looking at the two resonances from the $o$ protons, in $\left[\mathrm{RuH}_{2}(\mathrm{CO}) \mathrm{P}_{3}\right]$, the resonances at $\delta 7.26$ and 7.4 correspond to $6\left(\mathrm{P}_{\mathrm{b}}\right)$ and $12 \mathrm{P}_{\mathrm{a}}$ ) protons as expected. When the same product is made from $\mathrm{CD}_{3} \mathrm{OD} / \mathrm{Na}$ (Figure $\mathrm{S} 32)$, the integrations correspond to 2.2 and 4.3 protons showing that very substantial $D$ has been incorporated into the $o$-positions. (11 - $12 \mathrm{D}$ per molecule). Further qualitative evidence for incorporation of $D$ into the $o$ positions of the phenyl rings comes from the fine structure of the resonances from the $m$ protons on $\mathrm{P}_{\mathrm{b}}$, which is absent from the related resonance in Figures $\mathrm{S} 31$ and arises from $\mathrm{H}_{m}-\mathrm{D}_{o}$ coupling. The incorporation of $D$ into the ortho positions is far in excess of the 4 that would be required to give 4 nondeuterated hydrides. We conclude that fast $\mathrm{H}-\mathrm{D}$ exchange occurs with the solvent in some intermediates along with loss of $\mathrm{HD} / \mathrm{H}_{2}$ or that $\mathrm{D}$ can be incorporated directly into the ligand from the solvent. 
This $\mathrm{H} / \mathrm{D}$ exchange must occur during the conversion of $\left[\mathrm{RuHClP}_{3}\right]$ to $\left[\mathrm{RuH}_{4} \mathrm{P}_{4}{ }_{4}\right]$ but the final product of this first step certainly only contains Ru-H. This is best seen from the hydride resonances of $\left[\operatorname{RuH}_{2}\left(\mathrm{~N}_{2}\right) \mathrm{P}_{3}\right]$, which very clearly shows the $\mathrm{H}-\mathrm{H}$ coupling of the dihydride with no enhancement of the low frequency peaks. The $\left[\mathrm{RuH}_{2} \mathrm{P}_{4}\right]$ hydride resonance is second order $\left(A A^{\prime} M M^{\prime} X X^{\prime}\right)$ and is identical whether the reaction is carried out in $\mathrm{CH}_{3} \mathrm{OH}$ or $\mathrm{CD}_{3} \mathrm{OD}$. [RuHDP $]$ ] would be expected to show a first order resonance approaching a doublet of quartets.

\section{Hydride composition for the final product from reaction of $\left[\mathrm{RuHClP}_{3}\right]$ with $\mathrm{Na} / \mathrm{CD}_{3} \mathrm{OD}$}

Figure $\mathrm{S} 31$ shows the integrated phenyl region of a final product $\left[\mathrm{RuH}_{2}(\mathrm{CO}) \mathrm{P}_{3}\right]$ obtained using $\left[\mathrm{RuHClP_{3 }}\right]$ and $\mathrm{Na} / \mathrm{CH}_{3} \mathrm{OH}$ with each hydride signal set to have an integrated intensity of 1.0. Figure $\mathrm{S} 32$ is from a similar final product when using $\mathrm{Na} / \mathrm{CD}_{3} \mathrm{OD}$ once again with the equal intensity hydride resonances set at 1.0 These hydride resonances, which are shown in Figure $\mathrm{S} 3$ arise from the two isomers of $\left[\mathrm{RuHD}(\mathrm{CO}) \mathrm{P}^{\prime}{ }_{3}\right]$ together with some $\left[\mathrm{RuH}_{2}(\mathrm{CO}) \mathrm{P}_{3}^{\prime}\right]$.

We then analyse the integrations of the meta $\mathrm{H}$ atoms on the phenyl rings since they are distinct, free from interference by $\mathrm{OPPh}_{3}$ and should not have experienced any $\mathrm{H} / \mathrm{D}$ exchange. For the non-deuterated sample (Figure S31) the $m$ resonances from $P_{a}$ and $P_{b}$ integrate as 12.36 and 6.56 corresponding to 12 and 6 protons respectively. The similar integration for the deuterated sample (Figure S32) gives $P_{a} 24.81$ and $P_{b}$ 12.86, almost exactly double what is seen for the undeuterated sample. This means that there is on average $1 \mathrm{H}$ and $1 \mathrm{D}$ on each ruthenium and hence that the amount of $\left[\operatorname{RuH}_{2}(\mathrm{CO}) \mathrm{P}_{3}{ }_{3}\right]$ and of $\left[\operatorname{RuD}_{2}(\mathrm{CO}) \mathrm{P}_{3}\right]$ must be the same.

By integrating the individual peaks for each hydride signal in Figure $\mathrm{S} 3$, it is possible to work out the ratio of the two isomers of $\left[\operatorname{RuHD}(\mathrm{CO}) \mathrm{P}_{3}^{\prime}\right]$ (each 1.27) to $\left[\mathrm{RuH}_{2}(\mathrm{CO}) \mathrm{P}_{3}{ }_{3}\right]$ (1). Since $\left[\mathrm{RuD}_{2}(\mathrm{CO}) \mathrm{P}_{3}{ }_{3}\right]$ must also be present in the same amount as $\left[\mathrm{RuH}_{2}(\mathrm{CO}) \mathrm{P}_{3}^{\prime}\right]$. We can simulate the observed integrations if the proportions of $\left[\mathrm{RuH}_{2}(\mathrm{CO}) \mathrm{P}_{2}{ }_{2}\right]:\left[\mathrm{RuHD}(\mathrm{CO}) \mathrm{P}_{3}^{\prime}\right]$ (each isomer) : $\left[\operatorname{RuD}_{2}(\mathrm{CO}) \mathrm{P}_{3}^{\prime}{ }_{3}\right]$ is $0.22: 0.28: 0.28: 0.22$. 